\title{
Global implications of China as a manufacturing powerhouse
}
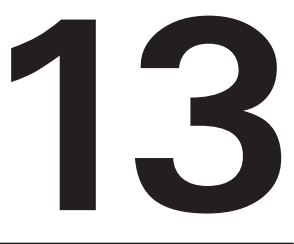

\section{Huw McKay and Ligang Song}

This study examines the nature and consequences of China's rise to the centre of world economic affairs through manufacturing-led development. The first half of the nineteenth century was characterised by the diffusion of Britain's new industrial strategy to Continental Europe; the second half featured the ascent of the United States to global prominence, before it then rose to pre-eminence in the first half of the twentieth century. The second half of the twentieth century saw first Japan and then the East Asian region rise to global relevance. In turn, the first half of the twenty-first century will be substantially shaped by China's continuing engagement with a strategy of manufacturing-led development.

The first section of this chapter provides historical context for a balanced consideration of Chinese and global prospects. We argue that the current wave of industrial and technological diffusion in the early twentyfirst century, led by China, while differing from waves in the past in some ways, has fundamental points of reference that are readily explicable under the strategic framework we employ. The analysis presents a key finding: genuine powerhouses 'make room for themselves' through rising competitiveness, the exploitation of their own resource endowment and domestic market development.

We see China diverting from its current industrialisation path - which exhibits a modest but not overwhelming bias towards external demandto a strategy of domestic market integration and internally driven development. This reorientation will be shaped by the unique constraints that China faces relative to its predecessors.

A major attendant theme is that the current trajectory of industrialisation will have to be altered when China becomes more actively engaged in dealing with structural issues at home and abroad against the background of the unwinding of global imbalances. This issue, which is the major subject of section two, has profound implications for Chinese economic strategy. 
The third section discusses the potential economic impact of climate change on the future pattern of growth in China. The basic question here is to what extent will any Chinese commitment to low carbon growth alter the future structure of the Chinese and global economies? The issue is significant as the earlier adopters of industrial strategies were not subject to any such constraint on growth. Further, China's relatively recent engagement with a manufacturing-led growth path, and its immense backwardness before this engagement, means that the middle phase of industrialisation - characterised by rapidly growing emission intensities and continuing increases in global market share - is still ahead of it. This is an uncomfortable reality for China and the world.

With the prospect that a global framework for emissions mitigation will move forward strongly in the next few years, coupled with the observation that conflict between manufacturing-led growth and the health of the biosphere is already starkly evident in China, such constraints could become increasingly binding.

The answers provided to each of these questions are conditional and preliminary. It is clear that to achieve a benign outcome, China itself will be required to adjust enormously. As such adjustments are made more easily at low levels of development, however, where the capital stock is still being rapidly built up from a modest base and strategy could be regarded as fluid, we are guardedly optimistic about China's prospects for and its ability to find its own space in the increasingly crowded global economy.

\section{China's emergence in comparative historical context}

\section{The historical diffusion of the manufacturing-led strategy}

The history of the world economy since the final quarter of the 1700s can be seen as a continuous but fluctuating process of technological diffusion conditioning the emergence of manufacturing-led national development strategies (Snooks 1999). Descriptive analyses of this process abound, with a chronological advance through the initial construction of longrun time series (Kuznets 1930; Clark 1940; Bairoch 1982), attempts at systematic taxonomy (Chenery et al. 1986; Gerschenkron 1962; Rostow 1971), accounting for growth and studying its convergence (Solow 1957; Denison 1967; Baumol 1986; Abramovitz 1986; Dowrick and Ngyuen 1989) and the eventual synthesis of these threads into turn-of-the-millennium 
global-level analysis (Maddison 2001). ${ }^{1}$ The efforts of these scholars, supplemented by the efforts of specialists concentrating on the time paths of individual countries, have provided an empirical basis for the study of long-run structural change at the national, regional and global levels.

A country's long-term growth pattern is determined by its choice of economic strategy, which is endogenous to decisions on saving and investment and is informed by the supply of labour and non-labour inputs and the state of indigenous technological attainment. Strategic direction will also be steered, to varying degrees, by the nature of the international system of the time, most directly through the cross-border availability of technology to allow 'leapfrogging' (Gerschenkron 1962; Brezis et al. 1991), but also through the more prosaic channels of goods, services, capital and labour flows. These choices and their outcomes will determine the productivity growth premium a country can achieve and hence the absolute and relative standard of living that it can attain.

The key feature of world history since the Industrial Revolution has been the spread of the overarching strategy of technological progress from the pioneering zones to those regions with the ambition and drive to engage with and eventually join the core. This strategic transition has been associated with dynamic competition for global leadership and a fluid distribution of economic gravity. China's formidable rise as a manufacturing powerhouse is the latest example of this continuing process.

In addition to a consideration of the usual macroeconomic variables, we have assembled long time series of urbanisation rates, infrastructure investment, metal and energy intensity and automobile penetration to add a practical edge to the discussion. These indicators have been shown to contain substantial information on the development process (Song and Yu 2007; McKay 2008b) and are essential metrics for assessing the scale of global adaptation to the emergence of a new powerhouse.

\section{The basics: how China compares ${ }^{2}$}

China began its rise to global prominence from a very low base. In terms of the productivity frontier, which we define as the highest realised gross domestic product (GDP) per capita level of a major nation at any point in time, China was extremely backward when it initially engaged with the world. (Here we use the raw national accounts measure of GDP, with all its weaknesses.) The relative output per person of the United States, Japan, South Korea and China in their respective sample periods can be compared 
(Figure 13.1). In 1980, Chinese productivity was just 2.1 per cent of the frontier. That compares with 20 per cent for Japan in 1950 (and 26 per cent in 1900), 11 per cent for South Korea in 1960 and 75 per cent for the United States in 1870. As of 2008, nearly three decades on, the Chinese enjoy per capita output just below 13 per cent of the frontier, as represented by the United States. That is close enough to the position of South Korea at the beginning of its high-growth era, a little more than half the level of postWorld War II Japan and exactly half of the relative Japanese level in 1900. On this basis, we can safely classify China's industrialisation as immature in terms of the relative rise in living standards it has achieved.

Figure 13.1 Relative output per capita (years from the start of modern industrial development)

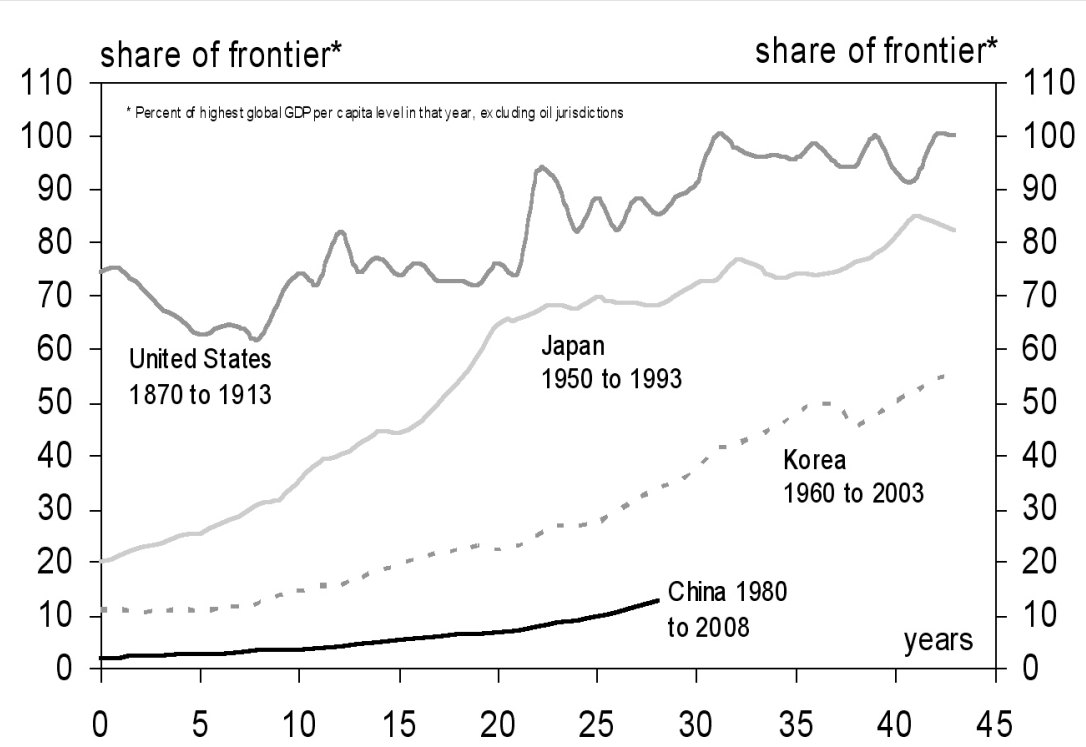

Sources: For China, International Monetary Fund (IMF) 2009, World Economic Outlook Database, April, International Monetary Fund, Washington, DC, < http://www.imf.org/external/ pubs/ft/weo/2009/01/weodata/>; others, Maddison, A. 2009, Historical Statistics of the World Economy: 1-2006AD, March update, Groningen Growth and Development Centre, Groningen, The Netherlands, < http://www.ggdc.net/maddison/>

Equally, China's GDP per capita level in absolute terms is still well short of the levels associated with the deceleration of latecomer growth and a peak in the industrial value-added share of output. This point is somewhere in the area between US\$10 000 and US $\$ 15000$ per capita in purchasing power parity (PPP) terms (Garnaut et al. 2008; Perkins and Rawski 2007; McKay 2008b). China attained a PPP GDP per capita level of US\$5962 
in 2008 and, on current projections by the International Monetary Fund (IMF), it will not reach the $\$ 10000$ per capita level until 2014. That said, China is an outlier in the sample with a high industrial value-added share before its policy of engagement, a relic of the self-sufficiency ethic and the pervasive price distortions that underpinned the pre-1978 economy. We return to this point in section three.

In terms of urbanisation levels, about one-fifth of the Chinese population lived in urban settings in 1980 - a level reached in Japan by the late 1920s, by South Korea in 1950 and by the United States in 1860. China's urbanisation level advanced to about 45 per cent in 2008 - equivalent to Japan in the mid-1950s, South Korea about the time of the first oil shock and the years immediately before World War I in the United States. China is set to converge with the global average of about 60 per cent in 2030 on projections by the United Nations (UN 2007). The United States reached that level about the end of World War II, Japan in the mid-1960s and South Korea in the mid-1980s (Figure 13.2).

\section{Figure 13.2 Long-run rates of urbanisation}

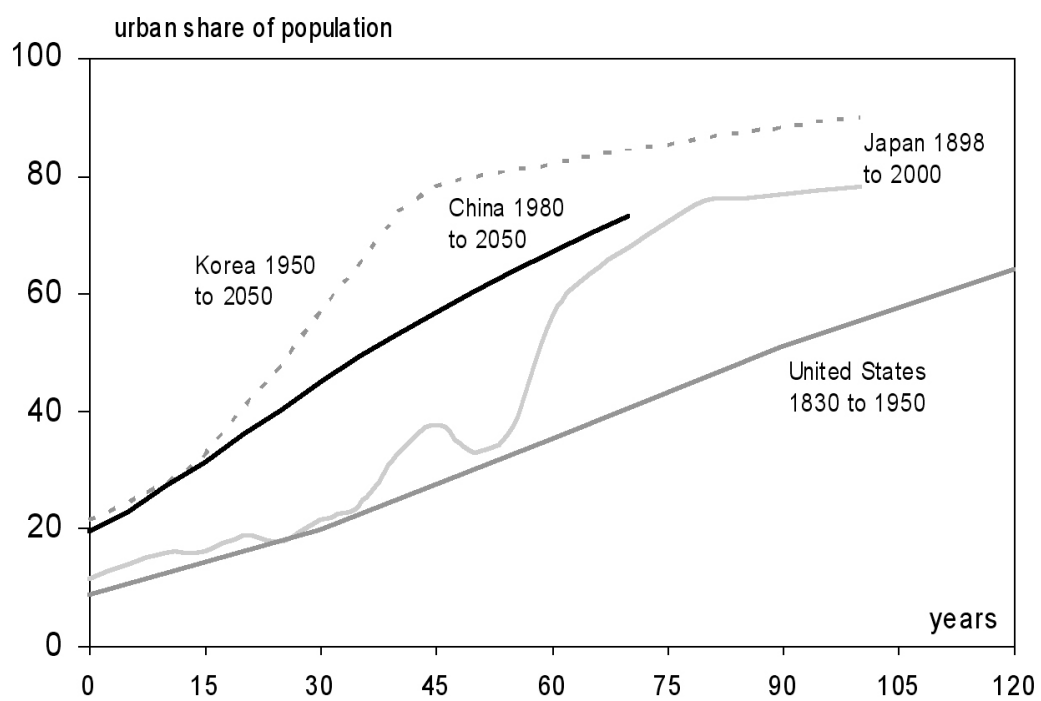

Sources: Figures for China, South Korea, Japan and the United States from 1950 from United Nations (UN) 2007, World Urbanization Prospects: The 2007 revision, United Nations, New York, < http://www.un.org/esa/population/publications/WUP2005/2005WUP_DataTables2.pdf > ; for Japan before 1950, from Japanese Statistics Bureau 2009, Historical Statistics of Japan, Japanese Statistics Bureau, Tokyo, <http://www.stat.go.jp/english/data/chouki/index.htm > ; for the United States before 1950, from United States Bureau of Statistics (USBS) various years, Statistical Abstract of the United States, United States Bureau of Statistics, Washington, DC. 
China has maintained a higher investment share than our sample group. Gross capital formation has been on average 38 per cent of GDP since 1978, with a peak of 44.5 per cent in 1993 (Table 13.1). China's high investment share has been funded with an extraordinary supply of savings, averaging 41 per cent of GDP for the period, with a peak of 53 per cent in 2008.

\section{Table 13.1 Investment to GDP ratios during rapid industrialisation periods}

\begin{tabular}{c|c|c|c|c|c|c|c}
\hline Year & Japan & Year & $\begin{array}{c}\text { South } \\
\text { Korea }\end{array}$ & Year & China & Years & $\begin{array}{c}\text { United } \\
\text { States }\end{array}$ \\
\hline 1898 & 12.6 & 1963 & 13.4 & 1978 & 38.0 & $1869-78$ & 24.0 \\
\hline 1905 & 12.6 & 1968 & 27.0 & 1983 & 34.4 & $1879-88$ & 25.0 \\
\hline 1919 & 16.0 & 1973 & 25.6 & 1988 & 38.2 & $1889-98$ & 29.0 \\
\hline 1931 & 16.5 & 1978 & 33.1 & 1993 & 44.5 & $1899-1908$ & 29.0 \\
\hline 1938 & 27.6 & 1983 & 29.0 & 1998 & 37.1 & & \\
\hline 1954 & 20.9 & 1988 & 31.4 & 2003 & 41.2 & & \\
\hline 1961 & 35.2 & 1993 & 35.7 & 2008 & 43.5 & & \\
\hline 1970 & 39.8 & 1998 & 25.0 & & & & \\
\hline 1980 & 32.8 & 2003 & 30.0 & & & & \\
\hline 1990 & 33.1 & & & & & & \\
\hline
\end{tabular}

Notes: Japanese figures up to 1961 are gross fixed capital formation; all other figures are gross capital formation - that is, they include inventories.

Sources: For China and South Korea, World Bank n.d., World Development Indicators, The World Bank, Washington, DC; for Japan for 1961 onwards, World Bank n.d., World Development Indicators, The World Bank, Washington, DC, and for 1898-1961, Ohkawa, K. and Rosovsky, H. 1968, 'Postwar Japanese growth in historical perspective: a second look', in L. Klein and K. Ohkawa (eds), Economic Growth: The Japanese experience since the Meiji era, Richard D. Irwin Inc., Homewood, III., Tables 1-7, p. 22; for the United States, Gallman, R. E. 2000, 'Economic growth and structural change in the long nineteenth century', in S. E. Engerman and R. E. Gallman (eds), The Cambridge History of the United States. Volume II: The long nineteenth century, Cambridge University Press, New York, Table 1.14, p. 50.

Despite the large proportion of expenditure devoted to capital formation since 1978, China still invests far less per capita than the comparator nations. Chinese investment per capita was about 2 per cent of the high-income level of the Organisation for Economic Cooperation and Development (OECD) countries in 1978. That compares with 4.8 per cent for South Korea in 1960. By this time, Japan was already investing 27 per cent more per capita than the high-income group - on its way to twin peaks of 238 per cent in 1970 and 1991. By 2007, China had just moved beyond 10 per cent of the high-income OECD level of capital spending per capita. Suffice to say that China's capital stock is still very shallow in relative terms. ${ }^{3}$ 
Turning now to infrastructure provision, in terms of roads, the experience of China looks very similar to that of Japan between the late 1800s and the mid-1920s (Figure 13.3). South Korea kept pace with the other two for the first 25 years or so, before the Chinese and Japanese investments in roads really took off. The United States was off the pace in the road stakes (taking data from 1900-30), but it led the way in railway investment (data from the last 30 years of the 1800s). China has been a notable laggard in the area of railways (Figure 13.4), although the indications are that the next few years will see a major investment in transcontinental trunk lines and intra-city commuter systems.

\section{Figure 13.3 Investment in infrastructure: roads}

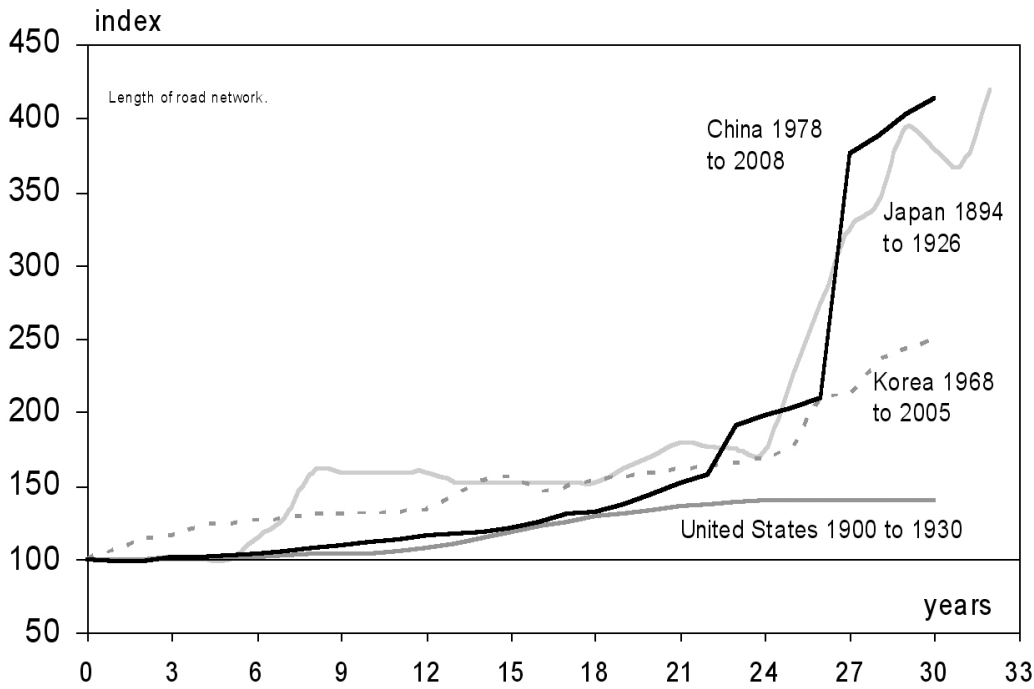

Sources: For China and Korea, CEIC n.d., CEIC Database, CEIC Data Company Limited, <www.ceicdata.com>; for Japan, Japanese Statistics Bureau 2009, Historical Statistics of Japan, Japanese Statistics Bureau, Tokyo, <http://www.stat.go.jp/english/data/ chouki/index.htm>; for the United States, United States Federal Highway Administration (USFHA) 2008, Highway Statistics 2007, United States Federal Highway Administration, <http://www.fhwa.dot.gov/policyinformation/statistics/2007/vmt421.cfm > 


\section{Figure 13.4 Investment in infrastructure: railways}

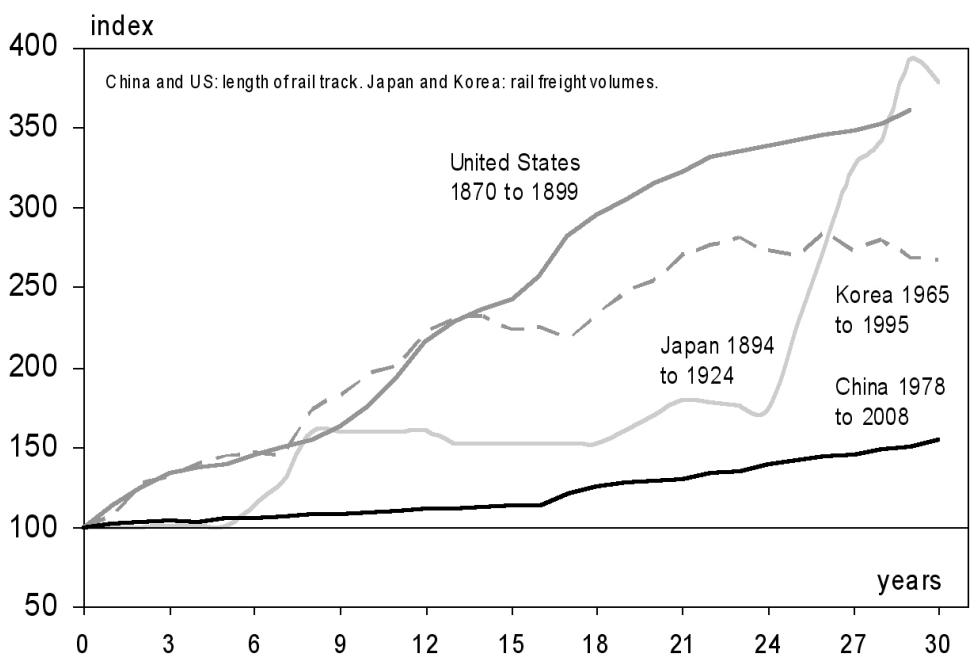

Sources: For China and Korea, CEIC n.d., CEIC Database, CEIC Data Company Limited, <www.ceicdata.com>; for Japan, Japanese Statistics Bureau 2009, Historical Statistics of Japan, Japanese Statistics Bureau, Tokyo, < http://www.stat.go.jp/english/data/chouki/index.htm > ; for the United States, Fishlow, A. 2000, 'Internal transportation in the nineteenth and early twentieth centuries', in S. E. Engerman and R. E. Gallman (eds), The Cambridge History of the United States. Volume II: The long nineteenth century, Cambridge University Press, New York, pp. 543-642.

Where resource intensity is concerned, in absolute terms China remains at the low end of the spectrum in per capita terms, although relative to its own income level consumption is quite high. Compared with US steel output per capita in 1900, China was at just 27 per cent in 1978 (Figure 13.5). China did not surpass the United States' 1900 level until the early years of the current decade, although it has since accelerated to more than 300 per cent of this benchmark.

As far as total commercial energy use is concerned, China was selfsufficient in the aggregate until the early years of the current decade. The United States was self-sufficient in petroleum products until 1957 (Bairoch 1993:61), by which time the country already had 327 cars per 1000 residents - on the way to a peak of 547 in 1988. Japan attained the 1957 US level of auto penetration in the late 1990s. It took South Korea until 2006 to reach this level. In 2006, China had just 18 cars per 1000 residents - up from just eight in 2002-yet it was already consuming more than double its annual domestic supply of approximately three million barrels a day of crude oil. The predictable rise in Chinese per capita consumption of resources will put a great deal of pressure on the global supply complex. 
Figure 13.5 Long-run steel output per capita

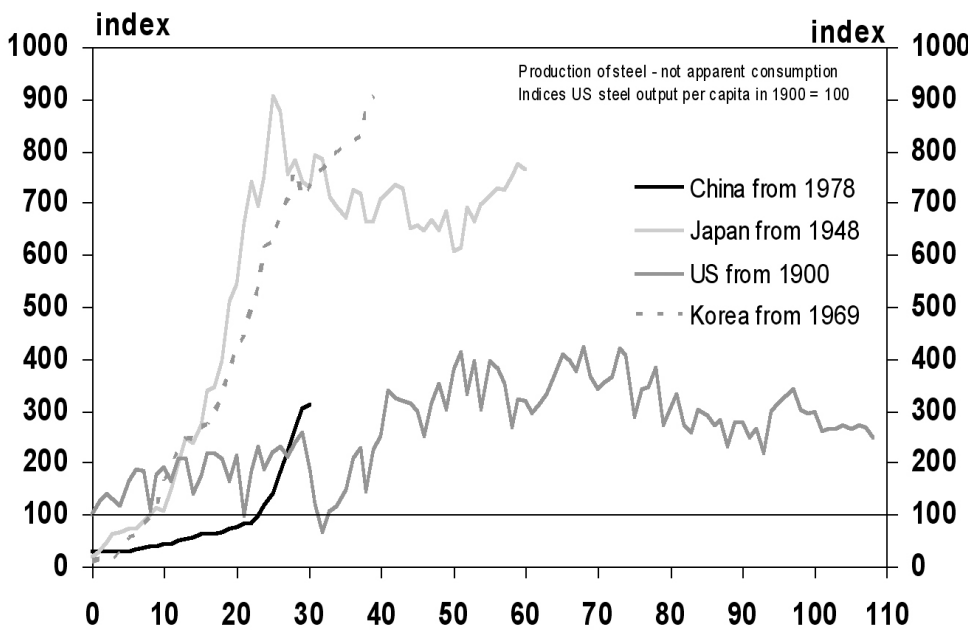

Sources: For China and Korea, International Iron and Steel Institute updated using CEIC n.d., CEIC Database, CEIC Data Company Limited, <www.ceicdata.com>; for Japan, Japanese Statistics Bureau 2009, Historical Statistics of Japan, Japanese Statistics Bureau, Tokyo, <http://www.stat.go.jp/english/data/chouki/index.htm > ; for the United States, United States Geological Survey (USGS) various years, Minerals Yearbooks, United States Geological Survey, <http://minerals.usgs.gov/minerals/pubs/>; population data from the sources cited above for individual countries.

The overall picture from this succinct survey of China's relative development position is that on most measures it is still well short of the point where, based on relevant historical precedents, it can be expected to:

- experience decelerating growth

- experience decelerating demands for capital formation

- see resource intensity diminish.

\section{Definitions of strategy: outward orientation versus export dependency}

The preceding section sought to describe the broad contours of China's development position relative to nominated comparators. This section will delve deeper to isolate the strategic differences between the nations in the group that has produced the outcomes detailed above.

A simple but effective way of differentiating between strategies is to track trends in global market shares. An economy that maintains an 
average export share of GDP will expand its share of global exports by the same fraction as it expands its share of global output. Extending the logic, an economy expanding its share of global exports faster than its share of global GDP is betraying an outward bias and vice versa.

Keeping these relationships in mind, consider Figure 13.6. A balanced economy replicating the global average structure will have a scatter that describes a 45 degree line, moving along that schedule as its rate of growth moves from above to below the global average. The curves described by our sample countries are highly instructive regarding the development of economic strategies that in turn determine structure.

\section{Figure 13.6 Global export and GDP shares}

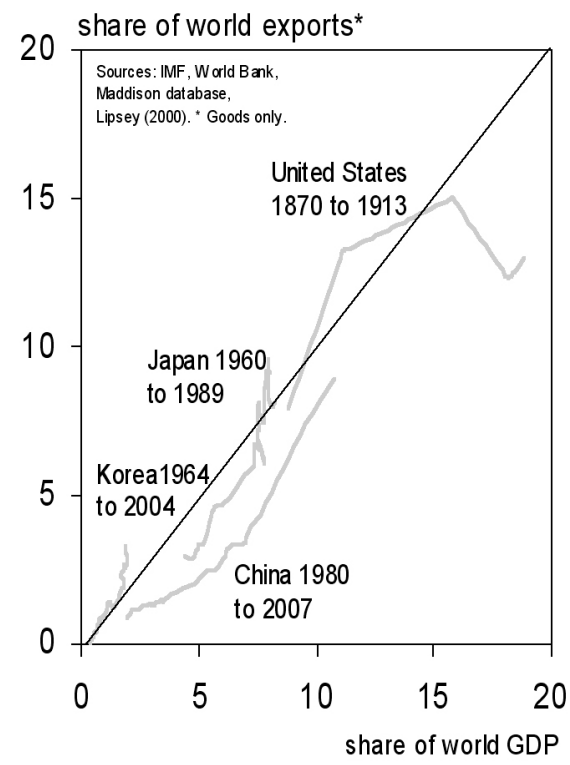

Sources: Merchandise export shares after 1960 are compiled from information in the World Bank n.d., World Development Indicators, The World Bank, Washington, DC; US data are from Lipsey, R. E. 2000, 'US foreign trade and the balance of payments, 1800-1913', in S. E. Engerman and R. E. Gallman (eds), The Cambridge History of the United States. Volume II: The long nineteenth century, Cambridge University Press, New York, Table 15.1, p. 688; world GDP shares are from Maddison, A. 2009, Historical Statistics of the World Economy: 1-2006AD, March update, Groningen Growth and Development Centre, Groningen, The Netherlands, <http://www.ggdc.net/maddison/>, World Bank n.d., World Development Indicators, The World Bank, Washington, DC and International Monetary Fund (IMF) 2009, World Economic Outlook Database, April, International Monetary Fund, Washington, DC, <http://www.imf. org/external/pubs/ft/weo/2009/01/weodata/> 
For the case of the United States in the second half of the nineteenth century, the data argue very strongly that its emergence was associated with a balanced strategy that neither ignored nor prioritised exports. Indeed, the observations for 1870, 1880 and 1890 in Figure 13.6 are near enough to the 45-degree line that we might classify the US strategy as close to a neutral one regarding the prevailing global structure. It is only between 1900 and 1913 that a decisive preference between external and internal demand can be seen-and that shift is decisively in the direction of the domestic economy. That is consistent with our knowledge of the major investments in domestic market integration that occurred during the previous century and the diffusion of the victorious North's industrialisation strategy across the continent in the post-bellum era.

The situation in the United States is a prime example of a large nation making room for its own industrial rise through the integration and then exploitation of internal markets. While external demand and foreign capital were certainly not trivial for US industrial development in the middle decades of the nineteenth century, they were becoming something of a footnote by the beginning of the twentieth. The United States would go on to take advantage of its domestic mega-market by developing massproduction techniques and enjoying the associated economies of scale. The successful application of this strategy eventually led to its domination of the global consumer durables industries until well into the second half of the twentieth century (Snooks 1997:384-90).

The growing competitiveness of US industry manifested itself in a rising share of manufactures in exports and a falling share of manufactures in imports (Table 13.2). The failures of Latin America's import-substitution policies, which go against comparative advantage (Lin 2008), have led economists to be suspicious of declining import shares in industrial economies. A declining import share in manufactures is, however, absolutely consistent with outward orientation if global export shares are also rising in the same areas. As competitiveness is absolute vis-a-vis local and foreign markets, there is no reason to differentiate between displacing imports and making inroads internationally. Both are positive functions of development. We will call the displacement of imports through rising competitiveness 'dynamic substitution' to distinguish it from discredited strategies of activist import substitution. 
Table 13.2 Dynamic substitution in the United States, 1820-1913

\begin{tabular}{l|c|c|c|c|c|c}
\hline Percentage & \multicolumn{2}{|c|}{ Raw materials } & \multicolumn{2}{c|}{ Semi-manufactures } & \multicolumn{2}{c}{ Manufactures } \\
\hline shares of... & Exports & Imports & Exports & Imports & Exports & Imports \\
\hline 1820 & 59.6 & 5.5 & 9.6 & 7.3 & 5.8 & 56.4 \\
\hline 1830 & 62.7 & 7.9 & 6.8 & 7.9 & 8.5 & 57.1 \\
\hline 1840 & 67.9 & 12.2 & 4.5 & 11.2 & 9.8 & 44.9 \\
\hline 1850 & 62.2 & 7.5 & 4.4 & 14.9 & 12.6 & 54.6 \\
\hline $1850-58$ & 60.3 & 8.7 & 4.1 & 13.2 & 12.6 & 52.5 \\
\hline $1859-68$ & 41.3 & 13 & 5.3 & 13.1 & 15.7 & 42.3 \\
\hline $1869-78$ & 44.1 & 15.7 & 4.7 & 12.8 & 15.9 & 34.6 \\
\hline $1879-88$ & 34.2 & 20.6 & 4.8 & 14.5 & 15.1 & 30.9 \\
\hline $1889-98$ & 32.9 & 24.7 & 7 & 13.9 & 17.1 & 26.7 \\
\hline $1899-1908$ & 29.2 & 33 & 11.9 & 16.6 & 24.6 & 25 \\
\hline $1904-13$ & 32.3 & 34.6 & 14.8 & 17.7 & 28.3 & 24.1 \\
\hline
\end{tabular}

Source: Lipsey, R. E. 2000, 'US foreign trade and the balance of payments, 1800-1913', in S. E. Engerman and R. E. Gallman (eds), The Cambridge History of the United States. Volume II: The long nineteenth century, Cambridge University Press, New York, Table 15.10, p. 702.

The United States, Japan and South Korea have each experienced periods when imports have fallen as a share of GDP. Further, through their phases of rapid industrialisation, dynamic substitution and a rising share of manufactures in exports were both evident. Each economy moved from running trade deficits to trade surpluses on the back of these trends. These developmental forces are most pronounced in the experiences of Japan and the United States, where there are more historical data to consider (Tables 13.2 and 13.3).

Table 13.3 Dynamic substitution in Japan, 1876-1940

\begin{tabular}{l|l|l|l|l|l}
\hline Exports & Food & Materials & Semi-manufactures & Manufactures & Other \\
\hline $1876-80$ & 38.1 & 11.1 & 41.6 & 4.7 & 4.5 \\
\hline $1894-98$ & 15.1 & 10.7 & 44.3 & 26.5 & 3.4 \\
\hline $1911-15$ & 10.8 & 7.9 & 49.5 & 30.4 & 1.4 \\
\hline $1921-25$ & 6.4 & 6 & 47.8 & 38.6 & 1.2 \\
\hline $1936-40$ & 9.9 & 4.3 & 26 & 57.4 & 2.4 \\
\hline Imports & Food & Materials & Semi-manufactures & Manufactures & Other \\
\hline $1876-80$ & 13.5 & 3.7 & 27.2 & 52.1 & 3.5 \\
\hline $1894-98$ & 23.2 & 22.5 & 18.2 & 34.1 & 2 \\
\hline $1911-15$ & 11.7 & 52.2 & 18.3 & 17.1 & 0.7 \\
\hline $1921-25$ & 14.1 & 49.3 & 18 & 17.9 & 0.7 \\
\hline $1936-40$ & 8.7 & 51.1 & 25.7 & 13 & 1.5 \\
\hline
\end{tabular}

Source: Baba, M. and Tatemoto, M. 1968, 'Foreign trade and economic growth', in L. Klein and K. Ohkawa (eds), Economic Growth: The Japanese experience since the Meiji era, Richard 
It is a common misconception that Japan was dependent on export growth through its rapid development phase. That was not the case. The economy was oriented outward but it was not export dependent. Again, the scatter plot is instructive. Figure 13.6 shows the Japanese economy advancing its share of both world GDP and world exports for two decades from 1960 on a trajectory parallel to the 45-degree line but firmly in the GDP segment. Only then does the curve turn north, implying that export shares continued to rise, but Japan had ceased to make material progress on the GDP axis. The curve then crosses the 45-degree line and enters the export segment of the figure space. This kinked curve hints at a major turning point for the economy that was not helpful for its relative advancement.

The Chinese economy initially moved decisively in the direction of expanding its share of world GDP faster than its share of exports in the 1980s. The economy then shifted course, with a mild bias towards exports pushing the curve back towards the 45-degree line from 1990 or so. The finishing point is, however, still comfortably in the GDP segment, indicating that the recent bias towards exports has been a relative rather than an absolute phenomenon.

The importance of inward foreign direct investment (FDI) (Chen 2007), the rise of the component trade (Athukorala and Yamashita 2008) and the associated dominance of foreign-funded firms in Chinese trade activity combine to inflate the importance of 'headline' exports to aggregate income. Figure 13.7 adjusts for this factor by separating foreign-funded firms from indigenous ones. The outcome is stark. Indigenous firms have made respectable progress in export markets, but their efforts look feeble relative to foreign-funded firms, as shown by the rapidly widening wedge between the two curves. Clearly, the attitudes of multinational manufacturers to China as a production and assembly base explain a material proportion of the emerging skew we observed in the Chinese curve in Figure 13.6. 
Figure 13.7 China's adjusted world export share

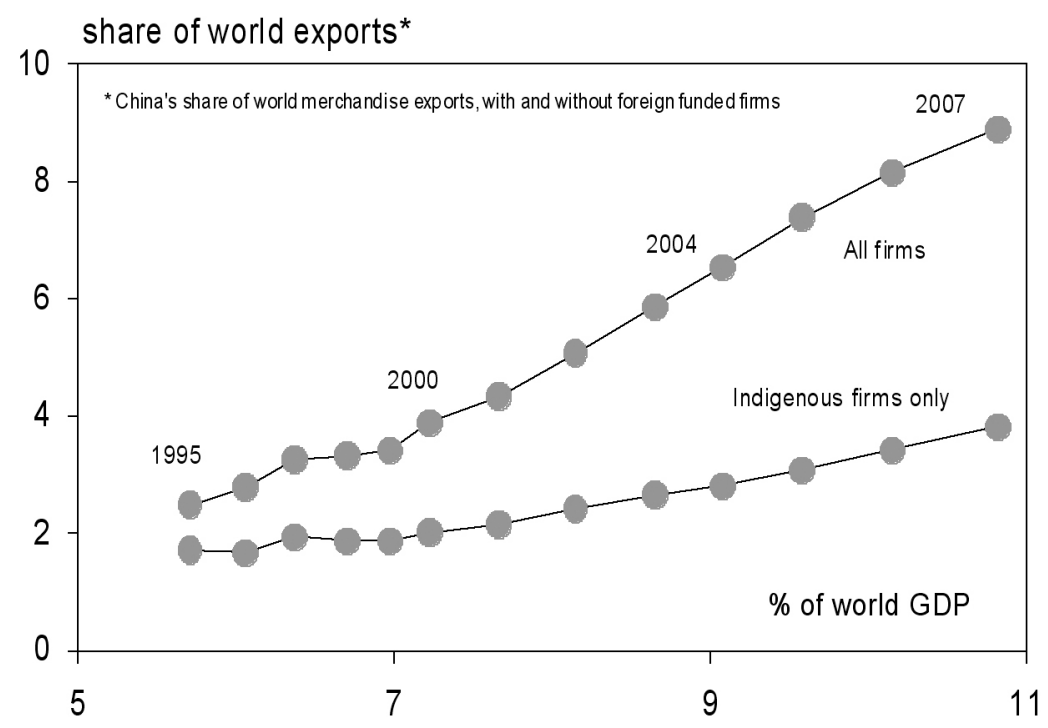

Sources: The foreign share of Chinese exports calculated from CEIC n.d., CEIC Database, CEIC Data Company Limited, <www.ceicdata.com> For global export and output shares: merchandise export shares after 1960 are compiled from information in World Bank n.d., World Development Indicators, The World Bank, Washington, DC; World GDP shares are the International Monetary Fund (IMF) 2009, World Economic Outlook Database, April, International Monetary Fund, Washington, DC, http://www.imf.org/external/pubs/ft/weo/2009/01/ weodata/

The nature of the next kink in China's strategic curve will have major implications for the balance of the global economy and for China's longrun economic outcomes. If China were to go successfully down the route pursued by the United States in the late nineteenth century - seeking to make room for itself through developing and integrating its potential internal mega-market - it will continue to advance for decades to come. If China follows the post-1980 Japanese example — which entailed expanding its export market share from an already high base - its rate of relative gains will be lower, and they will exhaust sooner.

The evidence as stated argues that China has so far avoided moving too far down this economic cul-de-sac, although we revisit this theme at a sectoral level in section two and will qualify this finding at that time. On the other hand, efforts at domestic integration, proxied by the strength in inter-regional growth spill-overs, are still nascent (Golley and Groeneweld 2007). The rhetoric of the Chinese administration indicates that it understands these dynamics very well. In a complex world, however, it 
is not enough to choose the correct path from those observable in the historical record. Enacting structural change from above, in the absence of effective price signals across all relevant factor markets (Huang 2009), is no straightforward matter. Concerns about environmental impacts and food and resource security are also impinging on strategic options. The continuing adjustments required to address the real and financial imbalances evident in the world economy today are also a constraint. We now consider in turn these major factors that will feed in to strategic economic calculus in China in the long run.

\section{Imbalances in the world economy and China's future trajectory}

The emergence of major trade and financial imbalances between regions has been the key characteristic of the global economy in the current decade (Figure 13.8). In the real economy, these imbalances are inherently transpacific in nature, with the petro-economies thrown in. In the financial arena, the imbalances have a transatlantic bent. This separation is due to the uniqueness of China's interaction with the world. It has achieved a position of major relevance in terms of the real economy, with global shares of output, trade, emissions and commodity consumption that rank it as a tier-one power. On the other hand, it has a financial system and a framework of exchange arrangements that presently disallow it from achieving equivalent heft in the financial sphere, with the intermediation of real economy imbalances left by default to the financial systems of the industrialised countries. Given China's relatively low income per capita level, it is the undeveloped financial system that is perhaps less surprising.

It is against this backdrop of imbalances that China, and the other major nations and regions, must seek to alter the composition of their economic activity and eventually their balance sheets. The intense distress experienced across the globe as the financial de-leveraging process accelerated in the second half of 2008 (Devlin and McKay 2008) and the uneven signs of stabilisation observed since have not reduced the enormity of the challenge. Indeed, one might argue that in the industrialised countries, policy has been designed to avoid structural adjustment, rather than to embrace it. 
Figure $13.8 \mathrm{Global}$ imbalances: current account balances as a share of world GDP at PPP weights

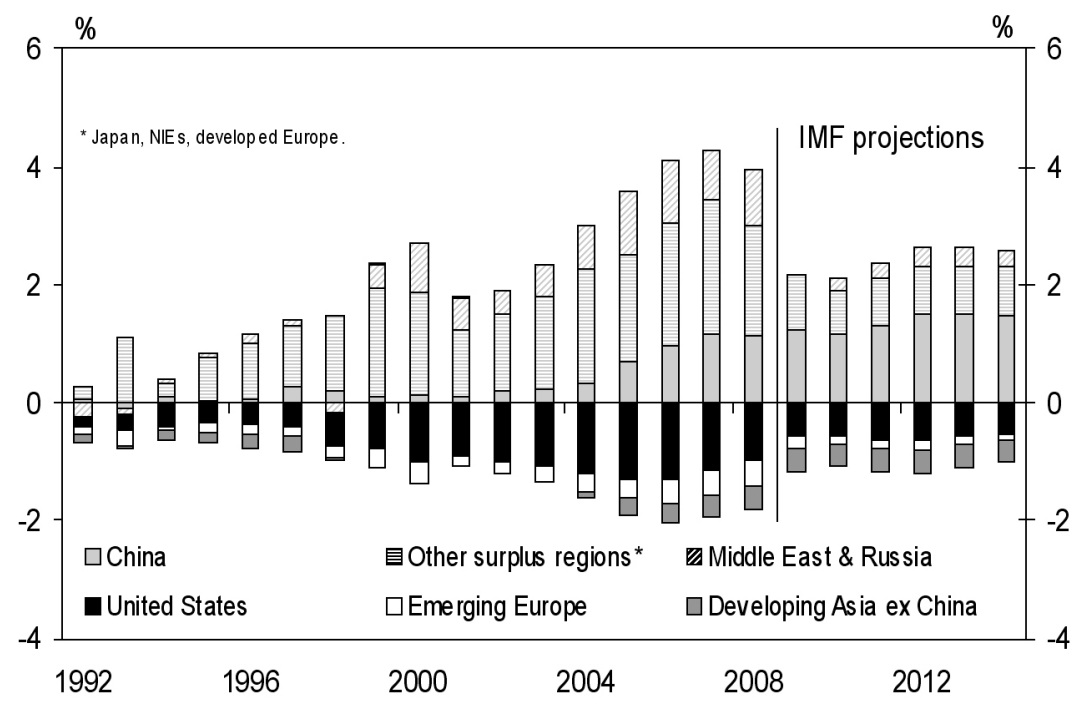

Sources: All underlying data and projections from International Monetary Fund (IMF) 2009, World Economic Outlook Database, April, International Monetary Fund, Washington, DC, <http://www.imf.org/external/pubs/ft/weo/2009/01/weodata/>, translated to shares of world GDP by the authors.

From a fundamental point of view, transpacific imbalances in the real economy boil down to a low rate of savings relative to investment in the United States and the opposite scenario in East Asia. Some analysts focus on the latter phenomenon, colloquially called the 'savings glut', and ascribe it catalytic force (Bernanke 2005; Cooper 2005). More subtly, a related theory apportions the 'blame' for the volume of capital flowing from emerging markets to the United States to the underlying theme of asymmetrical financial development (Caballero et al. 2008). Some focus rather narrowly on the pursuit of exchange rate stability in East Asia, linking the consequent foreign exchange reserve accumulation to export-driven strategies and mercantilist motivations (Dooley et al. 2003; Aizenman and Lee 2005). Others offer a more balanced approach and argue for significant adjustments from both deficit and surplus regions (Lee et al. 2004; Roubini and Setser 2005; IMF 2005:68-124).

Looking at China specifically, none of the unilateral prescriptions seems compelling in the least. Principally, they underwhelm as they fail to identify the drivers of the spectacular rise in the Chinese savings rate since 
the early years of this decade, which has simultaneously accommodated a historically high investment share of GDP and an enormous current account surplus. Relative to the somewhat predictable decline in the US savings rate in an era of loose fiscal (Roubini and Setser 2005; Brookings Institution 2004) and monetary (Taylor 2008) policy, in tandem with a social policy that encouraged the broadening of home ownership beyond its 'natural' perimeter, the Chinese experience needs significant explanation.

The Governor of the People's Bank of China has argued (Zhou 2008:1) that China's high savings ratio, and that of East Asia more generally, is related to 'tradition, cultural, family structure, and demographic structure and stage of economic development'. In Zhou's view, when the tangible factors of demography and development level are accounted for, but large unexplained differentials in savings rates are apparent - as in, say, East Asia vis-a-vis Latin America or Japan vis-a-vis the United States - culture must play a role in explaining these gaps.

Cross-country studies of savings rates emphasise their strong persistence/inertia, positive relationships to income per capita levels, credit, GDP growth and the terms of trade, weak relationships with rates of return and precautionary motivations, and negative relationships with the strength of social safety nets, the fiscal position and the dependency ratio (Loayza et al. 2000; IMF 2005:Ch.2). The Chinese savings rate has, however, consistently recorded outcomes well in excess of the predictions generated by cross-country frameworks, even before the recent jump (Kuijs 2006; IMF 2005:Box 2.1, pp. 96-7).

The Zhou approach - to attribute residual savings to cultural factorsis insufficient. While it is a convenient explanation for the persistence of relatively high savings rates in East Asia across time, it does not provide a suitable explanation for the jump in savings in the current decade. Complicating matters further, as Zhou himself points out later in the same speech, households - the sector seemingly most likely to define cultural norms - have maintained their savings as a share of GDP at a relatively stable level since the late 1990s. The rise in aggregate Chinese savings has been dominated by a major increase in the gross corporate savings rate, with some moderate assistance from an improving fiscal position (Kuijs 2006; Zhou 2008:3; Anderson 2006:6; IMF 2005:Box 2.1, pp. 96-7; Figure 13.9). The key to understanding the remarkable rise in Chinese savings, and the ultimate impact this phenomenon has had on inflaming the state of global imbalances, seems to lie with the corporate sector. 
Figure 13.9 Net financial investment by sector, China, 1992-2006

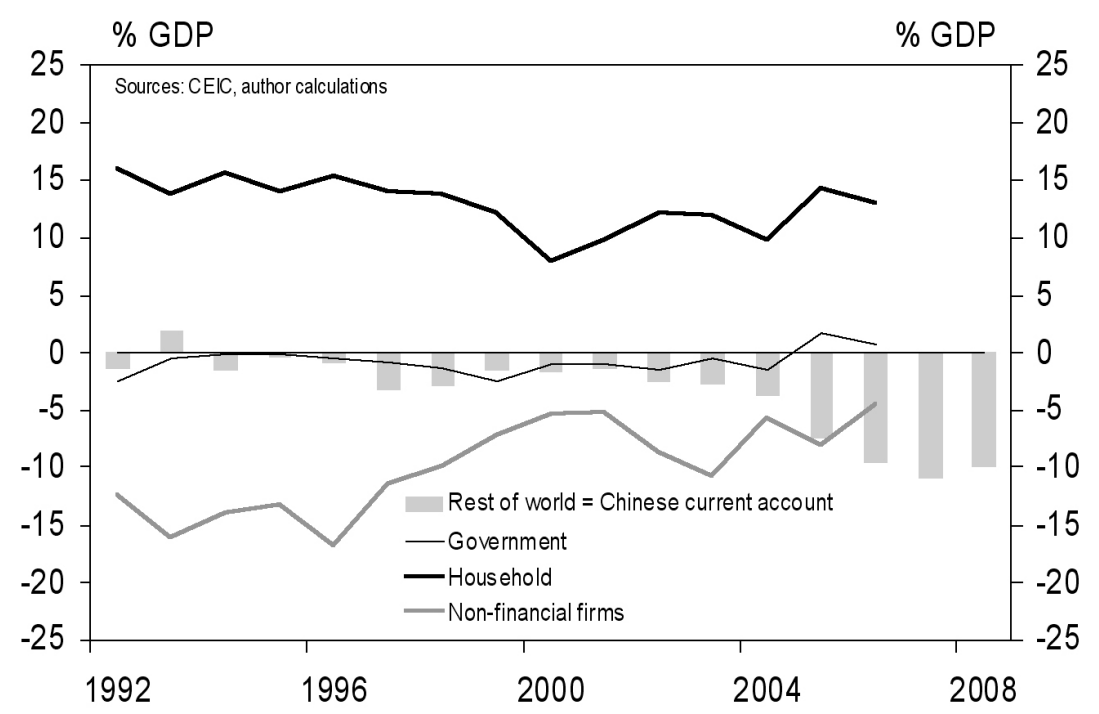

Source: Calculated from data in China's Flow of Funds accounts, accessed via CEIC n.d., CEIC Database, CEIC Data Company Limited, <www.ceicdata.com>

Identifying the corporate sector as the major contributor to the alteration of the savings story seems to reject the cultural hypothesis. Something more tangible is needed to explain this distinctive behaviour of firms. As it happens, the rise in corporate savings is readily explicable in economic terms. In brief, it is a function of excess capacity in heavy industry, coupled with the ability of Chinese firms to overcome this impediment, which is negative for profit margins, by expanding the volume of their sales through large market share gains at home and abroad. This development is the major discontinuity that explains the extraordinary rise in the Chinese current account balance since 2004 .

Consider Figures 13.10, 13.11 and 13.12 as a sequence. The first illustrates developments in the profitability of the corporate sector since 1985. There is a strong and intuitive relationship between the profit share of GDP and industrial profit margins ${ }^{4}$ for the majority of the period. The relationship has broken down since 2004, however, with the profit share of GDP rising sharply, but profit margins essentially stable. The last development is a predictable outcome of the re-emergence of excess capacity in heavy industry after rapid investment growth in the early years of the decade. The former is a puzzling outcome that needs further explanation. 
Figure 13.10 Excess capacity driving excess profits?

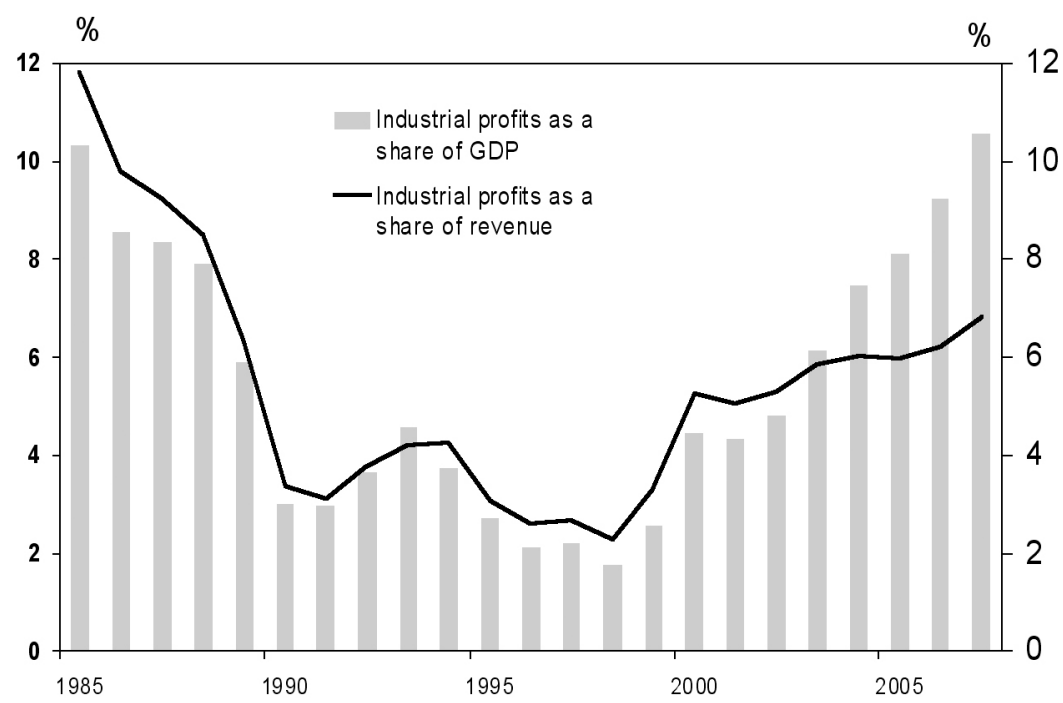

Source: All measures calculated from underlying data sourced via CEIC n.d., CEIC Database, CEIC Data Company Limited, <www.ceicdata.com >

Figure 13.11 Excess capacity in heavy industry requires market share gains at home and abroad

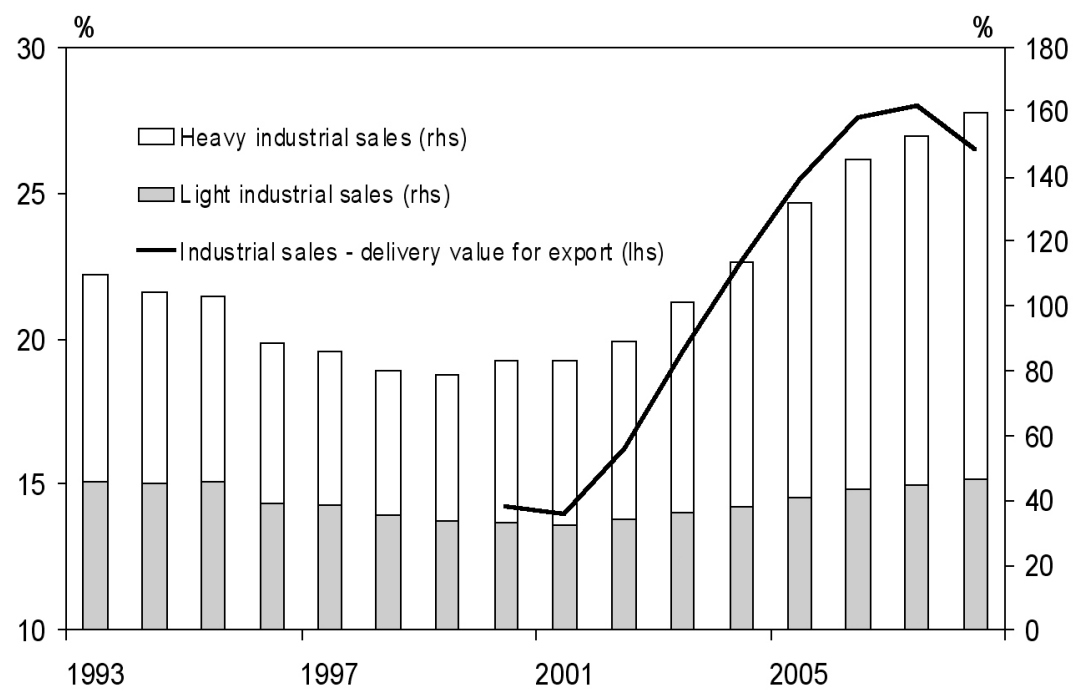

Source: All measures calculated from underlying data sourced via CEIC n.d., CEIC Database, CEIC Data Company Limited, <www.ceicdata.com > 
Figure 13.12 Decomposing China's trade balance by broad sector

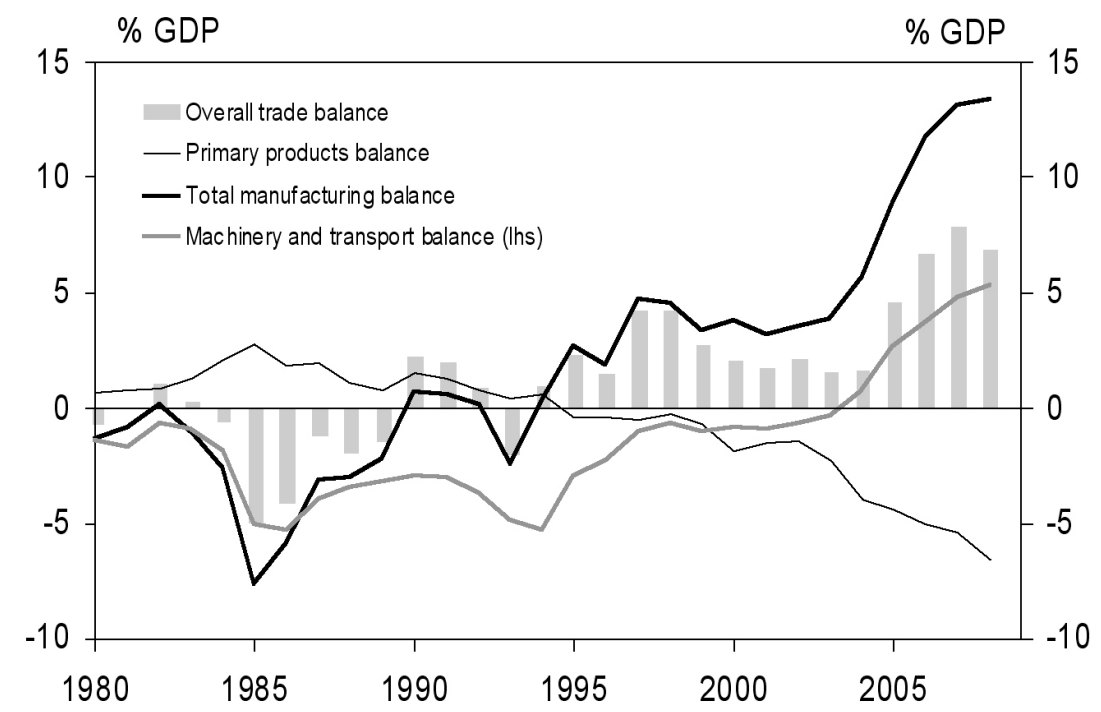

Source: All measures calculated from underlying data sourced via CEIC n.d., CEIC Database, CEIC Data Company Limited, <www.ceicdata.com>

Applying logic to this combination of circumstances, it is not difficult to deduce that when profit levels are rising but profit margins are not, an increase in the volume of sales must be substituting for the latter to achieve the former. Figure 13.11 illustrates this dynamic. Further, it highlights that it has been heavy industry that has provided the bulk of the increase in sales relative to GDP. ${ }^{5}$ This has been mirrored by a rise in the share of exports in industrial sales. Clearly, excess capacity provides the vehicle for a large increase in the volume of output and external demand provides an outlet for its sale. Increasing domestic market share at the expense of imports will produce a similar result at the aggregate level.

The end result of these trends has been a pronounced widening of the trade balance (Figure 13.12). Consistent with our identification of heavy industry as the major source of excess capacity in the current business cycle, it is the sectoral trade position of machinery and transport equipment that has contributed the most to the shift in the aggregate balance, moving from a deficit of 5.3 per cent of GDP in 1994 to a surplus of 5.3 per cent of GDP in 2008. That has assisted the overall manufacturing goods balance to improve by a spectacular 15.8 per cent of GDP since 1993. While this has naturally brought with it large demands for imported resources 
(a deterioration of 7 per cent of GDP in the primary products balance over the equivalent period), this has done little to curb the dramatic widening of the overall external imbalance.

Anderson (2006:8) has described this process as the cyclical 'expropriation' of market share by Chinese firms at home and abroad. It is this aspect of China's growth path that is imposing structural adjustments elsewhere. China's current account balance represented 1.1 per cent of world GDP in 2008 - a rise of about 1 per cent since the middle 1990s. The IMF's formal projections of the future development of global imbalances to 2014 (Figure 13.8) indicates that China's current account balance as a share of world GDP will increase slowly from the 2008 level to about 1.5 per cent.

Thinking about this projection carefully, we can ascertain that a moderation in China's current account relative to domestic GDP is assumed, as the Chinese economy will be increasing its share of the global output over this period. This view is consistent with underlying assumptions of stable household and corporate savings relative to GDP, but deteriorating public savings, consistent with the announced fiscal expansion. The adjustments expected elsewhere, however, are much more significant.

What can we infer from this? First, it would seem that these projections assume that structural changes are more likely to be imposed on the rest of the world by China, rather than the reverse. Second, it also implicitly assumes that the savings-investment conditions prevailing in China in 2008 are a reasonably stable constellation of affairs. From the foregoing discussion, we know that for these assumptions to be validated by events, Chinese heavy industry will have to keep expropriating external and domestic market share to keep profit levels high despite low margins, allowing aggregate savings to remain at a level consistent with a very large current account surplus. Alternatively, domestic and global demand for heavy industrial output could rise so rapidly that current capacity levels become more reasonable in a short timeframe. ${ }^{6}$ It is rarely courageous to forecast the status quo- - but this could be one of those circumstances.

To this point of the chapter, there has been no consideration of the reasons behind the re-emergence of excess capacity in the present business cycle phase. Our view is that rapid investment growth in heavy industry is directly related to the inefficient allocation of capital by the financial system - an allocation that is against China's present comparative advantage (Lin 2008). The preferential access to bank funding enjoyed by state-owned enterprises (SOEs); the lack of diversity in financial assets that 
gives banks preferential access to private savings; the prevalence of SOEs in the heavy-industrial sectors of the economy; the fragmented nature of heavy industry, in terms of geographical and industrial concentration; weak corporate governance and the historical absence of a dividend payment requirement for SOEs that jointly enable high retained earnings and their inefficient reinvestment; and the differential incentives of central and local administrators all contribute to an outsized share of investment funds being devoted to the addition of heavy-industrial capacity.

There are a number of options available to policymakers to improve the quality of resource allocation by the financial system. Many have already been taken, such as the move away from policy lending to commercial decision making, share market listings, the introduction of foreign expertise through equity injections, the introduction of foreign competition via WTO accession requirements and the encouragement of the corporate bond market. The acceleration of each of these trends, further progress on interest rate liberalisation (Song 2005), the deepening of inter-bank money markets and the further development of domestic accounting, legal and credit rating frameworks should all contribute positively to the future quality of savings allocation.

Financial system development is intimately associated with exchange rate regime choice, the design of exchange arrangements and the tools available for enacting monetary policy (McKay 2007; Prasad et al. 2005; Dobson and Masson 2009). Despite contrary evidence presented by the modelling community (for example, Lee et al. 2004), exchange rate adjustment in the surplus regions is often put forward as the key fulcrum in the imbalances story. Our view is that China's exchange rate regime choice has contributed to the current degree of imbalances as a central cog in the elaborate, path-dependent institutional structures that combine to produce a misallocation of resources internally, which manifests itself as an unwieldy external surplus. Given space constraints, we will go no further on this subject, referring the reader to the references above.

It is improvement in the quality of the financial sector's aggregate decision making that will catalyse a move back to a more balanced economic structure in China. A stronger, more competitive financial system could precipitate market-based adjustment profiles in areas such as the retirement of excess capacity in heavy industry, concentration in industries where fragmentation is a concern and improved access to credit for the private sector generally and for small and medium-sized enterprises in particular. 
A more productive allocation of investment funds between the coastal provinces and the central and western zones could also be forthcoming - a development that would do much to further the process of provincial convergence that seems the most likely future source of rapid economic growth. That brings us back to a point from the historical analysis of section one. Recall that Chinese economic strategy in the reform era was characterised as outward oriented but domestically led, with an emerging bias in the direction of external demand adduced only in the most recent run of annual observations. That fits nicely with the analysis of sectoral savings trends that highlighted the increasing importance of market share gains at the expense of foreign producers to alleviate excess capacity in heavy industry. We asserted that 'the nature of the next kink in China's strategic curve will have major implications for the balance of the global economy and for China's long-run economic outcomes'.

The United States created its own space in the global economy through the optimisation of internal strengths, while Japan's economic ascent exhausted when it deviated from a balanced strategy in the direction of export dependence. The implications for China are clear. Inefficient resource allocation has, over time, created large imbalances in China's domestic economy.

As the economy itself has grown, and its integration with the world has accelerated, these domestic imbalances have progressively spilled over into issues of a global scale. The China of today is not just making its own space - it is expropriating the place of others through the extraordinary growth of its heavy industrial capacity.

\section{Carbon constraints on growth and China's future trajectory}

A further major factor that will do much to determine the future course of Chinese industrialisation will be its response to the conflict between its current growth model and the biosphere - at the local, national, regional and global levels. While a 'Kuznetsian' inverse U-shaped relationship between certain measures of emissions per capita and developmental progress are apparent in cross-sectional empirical studies (Grossman and Krueger 1995), implying that China will at some point achieve a position where the marginal benefits of environmental amenity will exceed the perceived costs, the foregoing analysis has emphasised that China is still 
some way from the cluster of aggregate developmental trigger points. China's status as a global manufacturing powerhouse has thrust it to the forefront of the global debate on low carbon growth. Indeed, the world seems increasingly reluctant to let China find a congenial moment of its own choosing to tackle this fundamental issue.

The daunting task China faces if it is to achieve an emissions reduction target consistent with global mitigation efforts is comprehensively described by Stern (2008) and Garnaut (2008). As climate change is global in its origins and in its impacts, an effective response must therefore be organised globally, indicating that no major emitter can be excluded from a solution.

The awkward reality is that the rather compressed time frame for reaching an ambitious global emissions reduction target does not square with the development position of the Chinese economy. The current phase of China's industrialisation is characterised by a relatively high share of activity in the manufacturing sector, where high energy intensities prevail. The prevalence of heavy industrial activity growth in the current cycle was highlighted in section two. This sector was associated with the rapid rise in China's external surplus. It has also been the major source of emissions accelerating in recent years (Figure 13.13).

\section{Figure 13.13 Total fossil fuel emissions of the major economies, 1751-2006 (1000 metric tonnes)}

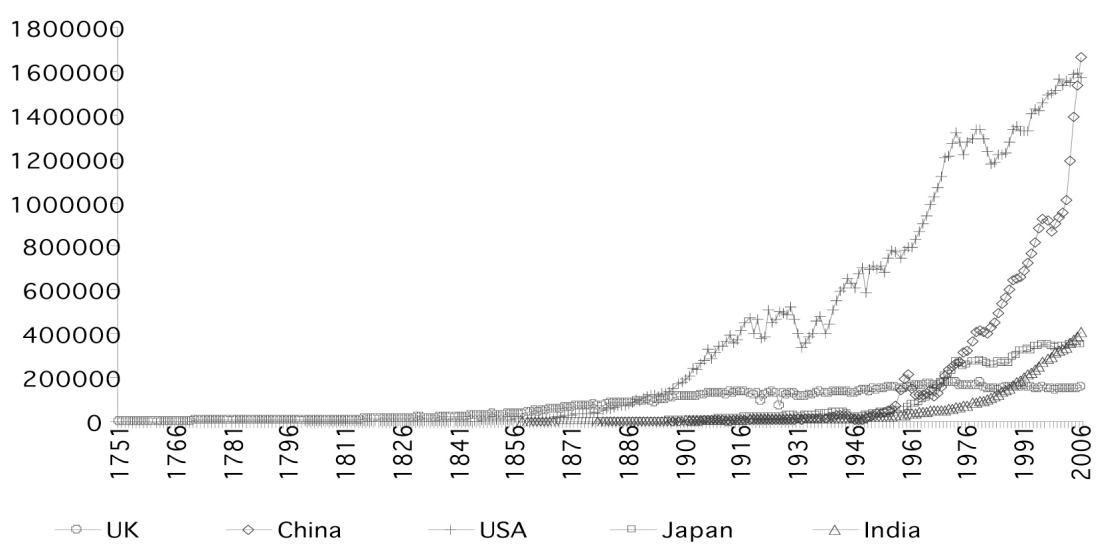

Source: All data from the Carbon Dioxide Information Analysis Center, Fossil-Fuel $\mathrm{CO}_{2}$ Emissions, <http://cdiac.ornl.gov/trends/emis/meth_reg.html> 
Rapid manufacturing-led growth is expected to persist for some time, whether one focuses solely on the projected increase in China's per capita income or other macroeconomic indicators such as auto penetration, metal and energy intensity, capital stock per capita or the level of urbanisation. The last is expected to rise from 45 per cent now to 60 per cent in 2020 and 73 per cent in 2050 (Figure 13.2). Given the strength of the underlying forces working against emissions reduction under the 'conventional' Chinese growth model, the model itself might have to give. An industrialisation path that achieves growth at the expense of profound environmental degradation is a finite strategy. Structural change in China is thus a prerequisite for a successful global program of emissions control.

Three questions stand out. First, what will be the practical and effective means through which China can confront this challenge of maintaining growth while reducing the emissions intensity of the economy? Second, to what extent will the adoption of a low-carbon growth model alter the pattern of industrialisation by prioritising energy intensity and changing the energy mix? Third, to what extent will a concerted effort to meet an ambitious global carbon emissions reduction target constrain Chinese economic growth? In other words, can China cheat economic gravity and decouple its carbon emissions increase from economic growth in the next chapter of its industrialisation?

The United States and China are two of the largest carbon emitters in the world. Together, they are responsible for about 40 per cent of the world's greenhouse gas emissions. The sheer size of these two economies obviously contributes strongly to this dominant share of emissions output, but at 33 per cent of world GDP at PPP weights, there is still some explaining to do.

China has joined the top ranks of emitters in a very short time. It took only about 30 years for China to climb from a relatively low base to the same level of emissions reached by the United States over more than a century. China's future trend of emissions - whether measured by total, by intensity or per capita-will depend on the composition and level of growth the economy generates through the next phase of industrialisation.

We contend that China will be encouraged to adjust due to rational self-interest, communicated by internal and external voices. It has certain strategic choices before it as it seeks to reorient its structural frameworks to incorporate both rapid economic growth and emissions reduction. 
These choices can be inferred from the simplicity of the well-known Kaya identity (Kaya 1990). ${ }^{7}$ The identity shows that there are four factors that contribute to a country's total carbon emissions: population, output per capita, the energy intensity output and the carbon intensity of the energy mix. Demographic variables are essentially set. China is also on track to achieve the official target of quadrupling 2000 per capita income by 2020 . This too will drive a continual increase in carbon emissions in the next decade or so. This is the developmental gravity that macro-strategy must lean heavily against.

In the context of the current discussion, the other two factors in the Kaya identity - namely, energy intensity and the energy mix-deserve special attention.

China has to rely primarily on lowering energy intensity and changing the energy mix to confront the challenge of emissions control. Both have strategic implications for future economic growth and the structure of the economy.

There are three commonly cited basic factors that determine the changes in a country's energy intensities in production over time. These are the structural adjustment towards high value-added production and the service sector, technological advancement to increase factor productivity and energy pricing to encourage the more efficient use of resources in production and consumption. Shifts in underlying comparative advantage will be crucial in determining the nature of structural change. We argue here that this process can be accelerated when a country is compelled to comply with emissions mitigation requirements, triggering the need to replace old, energy-intensive activities with new, environmentally friendly pursuits, while reassessing the conventional modes of production in the industrial sector. Private entrepreneurship, a competitive environment and strategic government leadership in the fields of pricing reform, innovation and education will all contribute positively to the development of low carbon growth. That is even before we mention the extremely powerful force of technological leapfrogging (Brezis et al. 1991) precipitated by diffusion through FDI and other forms of knowledge transfer-both tacit and concrete.

It is expected that technological diffusion through international cooperation on emissions adaptation and mitigation will help lower China's energy intensities in a significant way. China is relatively well endowed with a skilled labour force. According to the theory of Nelson and Phelps (1966), this is a key channel whereby the rate of technological 
diffusion can be raised. ${ }^{8}$ Needless to say, government policies and market and regulatory institutions are playing important roles in influencing the ways that energy prices work. In the case of China, allowing the pricing of energy products to gravitate upwards according to their true market values will be conducive to the further improvement of energy efficiency and the associated declines in intensity.

The historical experience of the fully industrialised countries of today demonstrates a certain pattern with respect to changing energy intensities through the various stages of development (Figure 13.14). This provides a point of reference for assessing the Chinese case.

\section{Figure 13.14 Long-run energy intensities of the major industrial countries, 1840-1990}

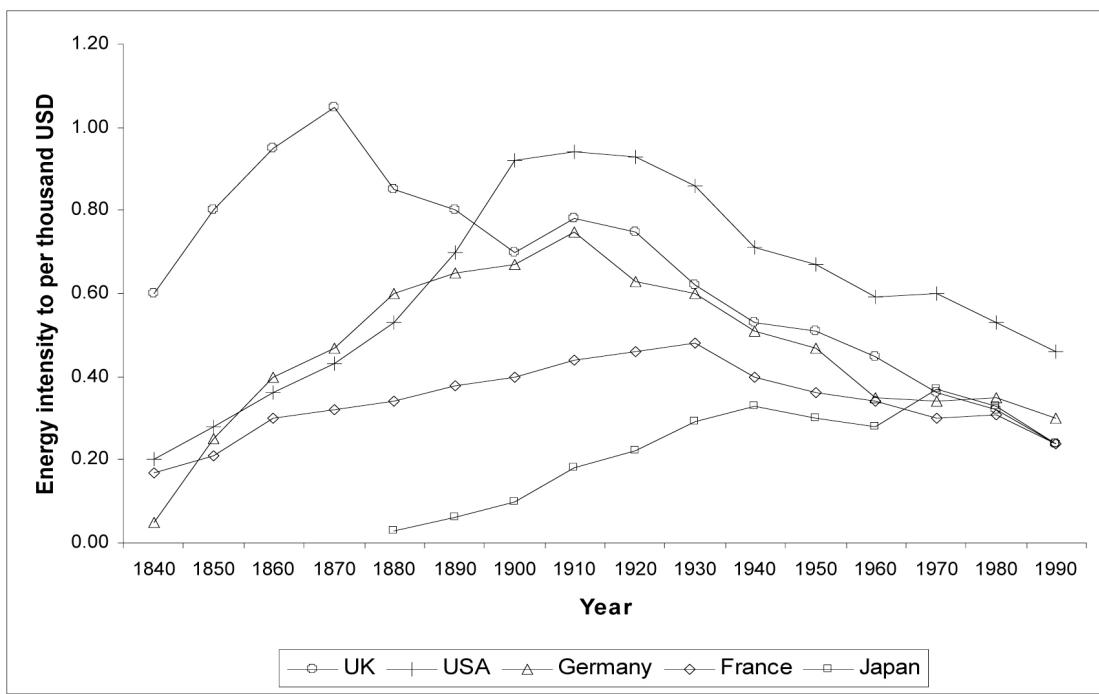

Source: Data estimated from Nishioka, S. 2008, 'A Japanese climate policy based on science, equity and cooperation', Asia-Pacific Review, vol. 15, no. 1, pp. 1-11, Figure 3.

The pattern of energy intensity in these countries shows a number of points of commonality. First, energy intensities rise in the early phases of industrialisation before peaking about the times when shares of industrial workers in the total labour force and industrial value added in total GDP reach high levels (for example, the United Kingdom in the 1870s and the United States in the 1910s). ${ }^{9}$ Second, peak energy intensities fell consistently with each successive wave of industrialisation, indicating accumulated technological advancement and diffusion, with a substantial beneficial 
impact on the latecomers. Third, energy intensities tended to converge to a relatively low level after the process of industrialisation was completed, reflecting the accelerated pace of economic integration, especially among the industrialised countries. The study by Wing (2008) shows that the declining energy intensity of the US economy is due mainly to industrial structural adjustment, with both inter and intra-industry structural change leading to energy-efficiency improvements across the whole economy.

With this historical pattern of change in energy intensity in mind, we observe that China has been making progress in lowering the energy intensity of its GDP. This measure has now been falling since the late 1970s to a significantly lower level in $2005^{10}$ (Garnaut 2008:Fig. 3.4; and Figure 18.1 in this book). The high level of energy intensities in the 1970s was due to the distinctive characteristics of industrialisation under the centrally planned system in which

China built an exceedingly energy-intensive and economically inefficient industrial structure...and economic resources were directed out of agriculture and into energy-intensive heavy industries like steel and cement. This had the effect that industry's share of economic output grew from 18 to 44 per cent, while the amount of energy required to produce each unit of economic output tripled. (Hallding et al. 2009:62)

This suggests that the observed pattern of energy intensity of Chinese production is not attributable solely to the normal course of industrialisation. It is also closely linked to the way in which the central planning system worked. The system itself ran against all three factors we have just identified - namely, it was rigid regarding structural change, sluggish in technological change and diffusion and, more importantly, fixed in pricing resources, with the predictable outcome of enormous price distortions in energy products and materials.

The reform carried out during the past 30 years has fundamentally transformed the planning system into a market system, but historical legacies remain, such as state monopoly in some key industries and administrative energy prices. Such legacies explain a large portion of the existing structural problems and the inefficient utilisation of resources. The Chinese economy is therefore characterised by the high resource costs per unit of output and the relatively high elasticities of energy and electricity consumption in comparison with mature industrialised countries (Figures 13.15 and 13.16). 
Figure 13.15 Elasticity of Chinese energy and electricity consumption, 1990-2007

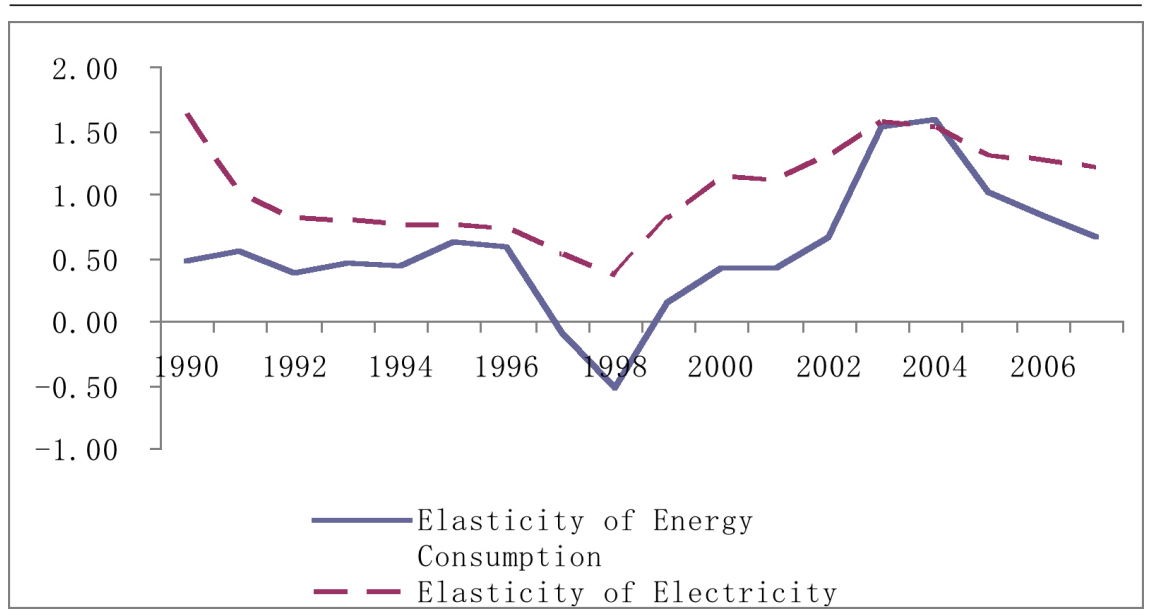

Source: All data from National Bureau of Statistics (NBS) various years, China Statistical Yearbook, China Statistics Press.

\section{Figure 13.16 International comparison of energy consumption} elasticities, selected countries, 2006 ${ }^{11}$

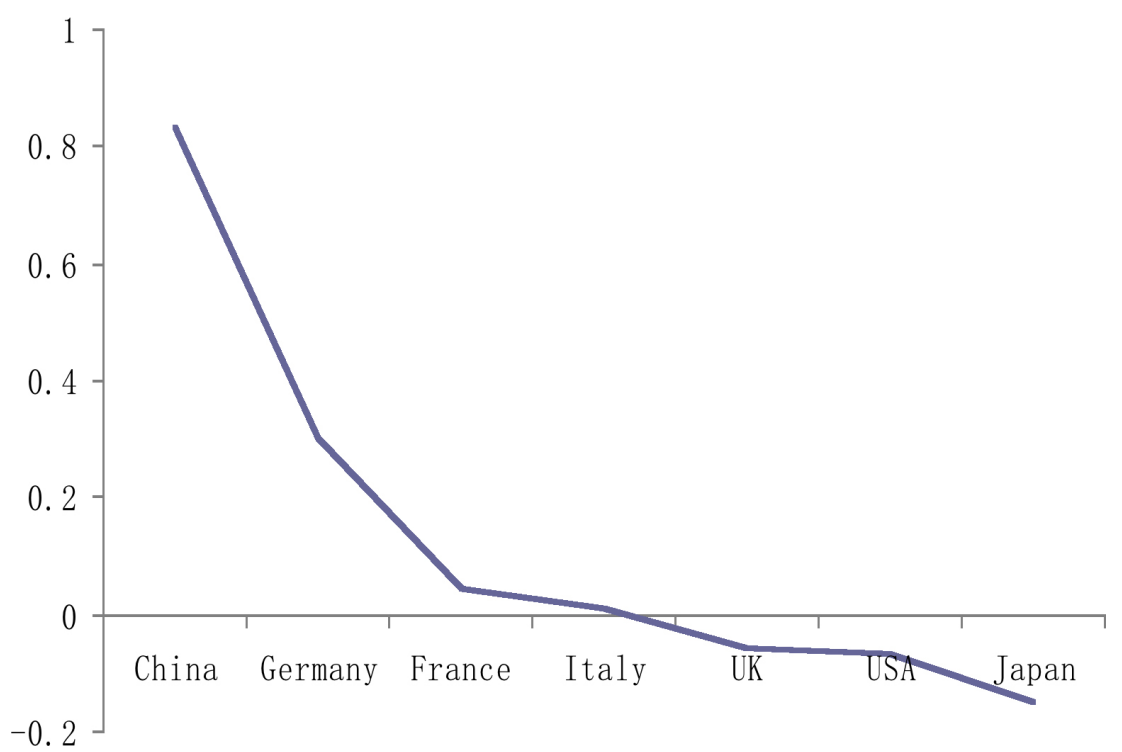

Source: Plotted using the data taken from National Bureau of Statistics (NBS) 2008, China Statistical Yearbook 2008, China Statistics Press, Beijing. 
This implies that for China to continue to drive down its energy intensities, it is crucial to deepen institutional reform. This would drive progress on structural change, technological advancement and diffusion at the most fundamental level by establishing a market-based pricing system for resources. If China is to transit through the next phase of industrialisation with relatively low energy intensities, reform of the pricing system is paramount. In the current decade, Chinese demand has been the major factor in a historically significant rise in commodity prices. Chinese users of these materials are, however, in many cases sheltered from the price rises that they have themselves done so much to produce. This perverse situation should be corrected without delay.

There is huge potential for China to narrow its technological gap with mature industrialised economies. This statement holds particularly strongly in the areas of green technologies. A concerted effort to procure flows of environmentally sound technology would enable China to quicken the pace of industrial structural change. In the first instance, immense gains can be predicted from a focus on technological transfer (and the retirement of old 'smoke-stack' capacity) in the energy-intensive industrial sectors such as iron and steel, base metals processing, power generation and chemicals. Technological advancement and more efficient use of energy (including coal) are needed to reconcile the twin objectives of growth and emissions reduction.

If a wholesale effort is launched in these areas, China will catch up more quickly and could even rise to leadership in the application of green technologies, given the economies of scale that would be associated with their use in China's projected mega-market, its strong foundation of human capital and, more importantly, the administrative determination to adopt a new model for economic growth. This is because China basically satisfies those conditions that must hold if introduction of a new technology is to lead to a leapfrogging process (Brezis et al. 1991). ${ }^{12}$

The realisation of the 'leapfrogging' process is also important in that it helps China avoid 'locked-in effects' in its major industrial sectors. This malignant effect on efficiency emerges when large-scale energy infrastructure development is only 'a simple replication of conventional technology' in the accelerated phase of industrialisation (Zhuang 2008:96). More simply, China should avoid over-investing in old technology and should move assertively to ensure that new additions to the capital stock satisfy the basic condition of the 'most energy efficient' technology 
available anywhere in the world. If that fundamental creed is adopted, a new pattern of industrialisation in China characterised by a shift towards producing more high-valued products driven by innovation and technology advancement could emerge. While some observers are pessimistic about China 'locking in' inefficient energy production capacity (Rosen and Houser 2007), others are more sanguine (Rawski 2008) - in line with our view.

The success of Chinese and other developing countries' endeavours for emissions reduction also hinges on whether industrialised countries transfer technology and finance to these countries. It is therefore critical that global efforts combating climate change formalise the proposition that the pace of technological diffusion between industrialised and developing countries must accelerate. Such diffusion is a critical assumption for achieving conditional convergence in the latest generation of orthodox growth models (Barro and Sali-i-Martin 2004). This indicates that industrialised countries have a crucial role to play in determining the future growth trajectories of China and its developing peers. The provision of the global public good of responding to climate change, and broadening the degree of success in the global convergence of living standards, centres on the development and diffusion of advanced technology.

Alterations to the energy mix will also help reduce China's total carbon emissions. An increasing share of renewable energy in its total energy consumption (the share is expected to reach 15 per cent by 2020) is a promising trend, but there is no quick fix. The biggest challenge is that China is essentially a coal-driven economy. Coal accounted for 70 per cent of the total primary energy consumption in China during the period 19952005 (Song and Sheng 2007) and the share will remain unchanged for the foreseeable future. China accounts for almost two-fifths of the world's total coal consumption, which is more than the United States, Russia and India combined. 'With a lifecycle of about 50 years the huge investments in coal fired power today will have considerable impact on the climate well into the middle of the century' (Hallding et al. 2009:71). Carbon capture and storage (CCS) technology, which has huge potential in China once the underlying concept reaches the point of widespread commercial application, is the major hope. Improvements in other technologies, such as coal washing and dust precipitation, will begin to reduce the carbon intensities of the economy at the margin (Shi 2008). 
Considering the issue of whether dealing with emissions reduction will materially compromise Chinese growth rates requires complex scenario analysis over long periods. One approach to this question is to estimate the costs of inaction, which could be high, thus negatively affecting the economy (Stern 2007; Garnaut 2008).

Fankhauser and Tol (2005) make the following points with respect to the possible impact of climate change on economic growth. First, 'negative climate change impacts are likely to reduce the rate of economic growth, but [are] unlikely to reverse a long-term path of increasing per capita income'. Second, 'climate change will always have a negative effect on the absolute capital stock, and the capital-labour ratio is also certain to decrease if agents are allowed to change their saving behaviour'. Third, 'as a result of climate change some sectors will grow faster than others, thereby changing the size and composition of GDP...such changes in the structure of an economy could have an impact on its long-term growth potential' (Fankhauser and Tol 2005:13). The last point is consistent with the argument for enhancing structural change and technological advancement in the process of dealing with carbon emissions. If successful, this could become a new source of economic growth, especially in renewable and low-carbon industries, as huge amounts of investment will be made in these segments. ${ }^{13}$

Industrialisation and globalisation have already turned China into a global manufacturing powerhouse. As we have noted, a large portion of China's global market share gains are attributable to the activities of foreign-funded firms. This has been the outcome of the working of China's underlying comparative advantage. This raises the issue of whether China's total carbon emissions should be examined in terms of production or should emissions consumed by an end user outside China be netted out. It seems that the latter calculation makes China less uncomfortable. The real issue, however, is to what extent the pursuit of a low-carbon growth strategy will alter the way that underlying comparative advantage works in efficiently determining China's pattern of trade. Imposing a cap on carbon emissions will disproportionately affect energy-intensive industries by increasing their costs of production and reducing their competitiveness. This should quicken the pace of industrial structural adjustment, which will otherwise take much more time to complete following the conventional industrialisation path. 
On the other hand, underlying comparative advantage will shift more quickly towards producing and trading those industrial goods that are more energy efficient and less pollution intensive. As argued by Hallding et al. (2009:105), the 'green leap forward' for Chinese industries, when it occurs, is likely to eliminate, or sharply diminish, the net export of embedded carbon. Moving towards more domestic consumption-driven growth, thereby bringing domestic demand more in line with domestic supply - a necessary condition for resolving global imbalances (as argued in section two) - will accelerate the pace of such an adjustment.

To conclude, there is a fair chance that China will demonstrate a different pattern of industrialisation from its major predecessors. As China rises inexorably towards the per capita income thresholds associated with developmental turning points, it is being presented with a challenge faced by none of its forebears: the requirement that it adopt a lowcarbon growth strategy. Any alternative to a low-carbon strategy would essentially preclude it from reversing its emissions growth path in a fashion timely enough for the world to avoid 'dangerous' climate change. The new strategy will be shaped by the imperative that the growth rate of carbon emissions is substantially lower than that of GDP. This can be done only through decisive progress on lowering the energy intensity of output and an associated shift in the energy mix towards renewables and cleaner applications of fossil-fuel sources.

If a substantial reduction of emissions consumption elasticities is successfully achieved, growth might not necessarily be compromised. Studies looking at China's long-term growth potential anticipate a deceleration in the second half of the next decade, even without incorporating assumptions related to mitigation regimes (Perkins and Rawski 2007; He et al. 2007; McKay 2008b). Any sustained effort to reduce excess capacity in heavy industry, and to reduce fragmentation in key sectors such as steel and automobiles, will be positive for long-run productivity growth and for emissions control.

It should also be noted that China's transition towards a low-carbon growth economy faces many uncertainties, such as incentive problems, the capacity of China's manufacturing industry to respond to the demand for introducing low-carbon technology, the incomplete reform of the energy market and the lack of appropriate institutions and policy mechanisms aimed at increasing energy efficiency and lowering carbon intensities. Success will require not only a commitment from China, but intensive international collaboration in technology and finance. 


\section{Conclusions}

China's emergence as a manufacturing powerhouse has altered the distribution of power in the world economy in irreversible fashion. The first half of the twenty-first century will be shaped substantially by the nature of China's continuing engagement with a strategy of manufacturingled development.

Our historical analysis has highlighted that China is still well short of the point in its developmental process where its growth might be reasonably expected to slow or the energy, resource and carbon intensity of growth to recede. On the other hand, structural adjustment within China and without the associated unwinding of imbalances could produce somewhat lower rates of economic growth for the next few years. A global environment in which carbon constraints become increasingly binding will produce a similar effect in the short run.

To take a benign view of long-run growth prospects, we argue that China must 'make its own space' by pursuing an internally led growth model that develops along emission-friendly lines. China has the great advantage of backwardness - in terms of both technological attainment and depth of capital stock. Given this starting point, we view future strategy as fluid rather than path dependent.

One profitable strategy that China might employ would be to approximate the incredibly fruitful mass-market integration efforts of the United States that eventually elevated it to its position of global primacy. The re-emergence of excess capacity in Chinese heavy industry, serious questions about the medium term ability of other major regions to accommodate further large gains in Chinese market share and the stark conflict between the contemporary style of industrial development and the health of the biosphere indicate strongly that now is the time to catalyse the required adjustment and reform processes that will underpin sustainable long-run prosperity. 


\section{References}

Abramovitz, M. 1986, 'Catching up, forging ahead and falling behind', The Journal of Economic History, vol. XLVI, no. 2 (June), pp. 385-406.

Aizenman, J. and Lee, J. 2005, International reserves: precautionary versus mercantilist views, theory and evidence, Working Paper 05/198, International Monetary Fund, Washington, DC.

Anderson, J. 2006, 'Rebalance this', UBS Investment Research, 12 December.

Athukorala, P.-C. and Yamashita, N. 2008, 'Global production sharing and US-China trade relations', in L. Song and W. T. Woo (eds), China's Dilemma: Economic growth, the environment and climate change, Asia Pacific Press and Brookings Institution Press, Canberra and Washington, DC, pp. 59-89.

Baba, M. and Tatemoto, M. 1968, 'Foreign trade and economic growth', in L. Klein and K. Ohkawa (eds), Economic Growth: The Japanese experience since the Meiji era, Richard D. Irwin Inc., Homewood, Ill., pp. 162-96.

Bairoch, P. 1982, 'International industrialisation levels from 1750 to 1980', The Journal of European Economic History, vol. 2, pp. 269-333.

_ 1993, Economics and World History: Myths and paradoxes, University of Chicago Press, Chicago.

Barro, R. J. and Sala-i-Martin, X. 2004, Economic Growth, Second edition, The MIT Press, Cambridge, Mass.

Baumol, W. 1986, 'Productivity growth, convergence and welfare: what the long run data show', The American Economic Review, vol. 76, no. 5 (December), pp. 1072-85.

Bernanke, B. 2005, The global savings glut and the US current account deficit, The Sandridge Lecture, Virginia Association of Economics, Richmond, Va., March.

Brezis, E., Krugman, P. and Tsiddon, D. 1991, Leapfrogging: a theory of cycles in national technological leadership, NBER Working Paper 3886, National Bureau of Economic Research, Cambridge, Mass.

Brookings Institution 2004, Event summary: restoring fiscal sanity while we still can, Brookings Institution, Washington, DC, $<$ http://www.brookings.edu/opinions/2004/0518budgetdeficit.aspx> 
Caballero, R. J., Farhi, E. and Gourinchas, P.-O. 2008, 'An equilibrium model of "global imbalances" and low interest rates', American Economic Review, vol. 98, no. 1 (March), pp. 358-93.

Cappiello, L. and Ferrucci, G. 2008, The sustainability of China's exchange rate policy and capital account liberalisation, ECB Occasional Paper Series, no. 82 (March), European Central Bank, Frankfurt am Main, Germany.

Carbon Dioxide Information Analysis Center n.d., Fossil-Fuel $\mathrm{CO}_{2}$ Emissions, <http://cdiac.ornl.gov/trends/emis/meth_reg.html>

CEIC n.d., CEIC Database, CEIC Data Company Limited, <www.ceicdata.com>

Chen, C. 2007, ‘Foreign direct investment in China: trends and characteristics after WTO accession', in R. Garnaut and L. Song (eds), China: Linking markets for growth, Asia Pacific Press, Canberra, pp. 197-224.

Chenery, H., Robinson, S. and Syrquin, M. 1986, Industrialisation and Growth: A comparative study, Oxford University Press, Oxford.

Clark, C. 1940, The Conditions of Economic Progress, Macmillan, London.

Cooper, R. N. 2005, Living with global imbalances: a contrarian view, Policy Brief, no. 5-3 (November), Peterson Institute for International Economics, Washington, DC.

Denison, E. 1967, Why Growth Rates Differ: Postwar experience in nine Western countries, Brookings Institution, Washington, DC.

Devlin, W. and McKay, H. 2008, 'The macroeconomic implications of financial de-leveraging', Economic Roundup, issue 4, pp. 47-75.

Dobson, W. and Masson, P. R. 2009, 'Will the renmimbi become a world currency?', China Economic Review, vol. 20, pp. 124-35.

Dooley, M., Folkerts-Landau, D. and Garber, P. 2003, An essay on the revised Bretton Woods system, NBER Working Paper, no. 9971, National Bureau of Economic Research, Cambridge, Mass.

Dowrick, S. and Nguyen D. T. 1989, 'OECD economic growth in the postwar period: catch-up and convergence', American Economic Review vol. 79, no. 5 (December), pp. 1010-30. 
Fankhauser, S. and Tol, R. S. J. 2005, 'On climate change and economic growth', Resource and Energy Economics, vol. 27, pp. 1-17.

Fishlow, A. 2000, 'Internal transportation in the nineteenth and early twentieth centuries', in S. E. Engerman and R. E. Gallman (eds), The Cambridge History of the United States. Volume II: The long nineteenth century, Cambridge University Press, New York, pp. 543-642.

Gallman, R. E. 2000, 'Economic growth and structural change in the long nineteenth century', in S. E. Engerman and R. E. Gallman (eds), The Cambridge History of the United States. Volume II: The long nineteenth century, Cambridge University Press, New York, pp. 1-56.

Garnaut, R. 2008, Climate Change Review Report, Cambridge University Press, Cambridge.

Garnaut, R., Howes, S., Jotzo, F. and Sheehan, P. 2008, Emissions in the Platinum Age: the implications of rapid development for climate change mitigation, Garnaut Review Working Paper, Revised draft, 2 May 2008, $<$ www.garnautreview.org.au >

Gerschenkron, A. 1962, Economic Backwardness in Historical Perspective, Harvard University Press, Cambridge, Mass.

Golley, J. and Groeneweld, N. 2007, 'Domestic market integration and inter-regional growth spillovers', in R. Garnaut and L. Song (eds), China: Linking markets for growth, Asia Pacific Press, Canberra, pp. 176-96.

Golley, J. and Tyers, R. 2006, 'China's growth to 2030: demographic change and the labour supply constraint', in R. Garnaut and L. Song (eds), The Turning Point in China's Economic Development, Asia Pacific Press, Canberra, pp. 203-26.

Grossman, G. and Krueger A. 1995, 'Economic growth and environment', Quarterly Journal of Economics, vol. 110, no. 2, pp. 353-77.

Hallding, K., Han, G. and Olsson, M. 2009, A Balancing Act: China's role in climate change, The Commission on Sustainable Development, Stockholm.

He, J., Li, S. and Polaski, S. 2007, 'China's economic prospects 2006-2020', Carnegie Papers, no. 83, April. 
Huang, Y. 2009, China's subsidised prosperity: the great ascendancy and structural risks, Unpublished manuscript.

International Monetary Fund (IMF) 2005, 'Global imbalances: a savings and investment perspective', World Economic Outlook, September, International Monetary Fund, Washington, DC, pp. 91-124.

2009. World Economic Outlook Database, April, International Monetary Fund, Washington, DC, <http://www.imf.org/external/ pubs/ft/weo/2009/01/weodata/>

Japanese Statistics Bureau 2009, Historical Statistics of Japan, Japanese Statistics Bureau, Tokyo, <http://www.stat.go.jp/english/data/chouki>

Kaya, Y., 1990, 'Impacts of carbon dioxide emission control on GDP growth: Interpretation of proposed scenarios', paper presented at IPCC Energy and Industry Subgroup Response Strategies Working Group, Paris, France.

Klein, L. and Ohkawa, K. (eds) 1968, Economic Growth: The Japanese experience since the Meiji era, Richard D. Irwin Inc., Homewood, Ill.

Kuijs, L. 2006, How will China's saving-investment balance evolve?, World Bank Policy Research Working Paper, no. 3958 (July), The World Bank, Washington, DC.

Kuznets, S. 1930, Secular Movements in Production and Prices, National Bureau for Economic Research, Boston.

Lee, J.-W, McKibbin, W. J. and Yung, C. P. 2004, Trans-Pacific trade imbalances: causes and cures, Lowy Institute Issues Brief, September, Lowy Insitute, Sydney.

Lin, J. Y. 2008, 'Rebalancing equity and efficiency for sustained growth', in L. Song and W. T. Woo (eds), China's Dilemma: Economic growth, the environment and climate change, Asia Pacific Press and Brookings Institution Press, Canberra and Washington, DC, pp. 90-109.

Lipsey, R. E. 2000, 'US foreign trade and the balance of payments, 1800-1913', in S. E. Engerman and R. E. Gallman (eds), The Cambridge History of the United States. Volume II: The long nineteenth century, Cambridge University Press, New York, pp. 685-732.

Loayza, N., Schmidt-Hebbel, K. and Serven, L. 2000, 'Saving in developing countries: an overview', The World Bank Economic Review, vol. 14, no. 3, pp. 393-414. 
McKay, H. 2007, 'Reforming China's exchange arrangements: monetary and financial sovereignty, sequencing and the foreign exchange market', in R. Garnaut and L. Song (eds), China: Linking markets for growth, Asia Pacific Press, Canberra, pp. 290-315.

2008a, Asian industrialisation: a strategic analysis with a memorandum on the Australian response, Global Dynamic Systems Centre Working Papers, no. 4 (June), Global Dynamic Systems Centre, Canberra.

2008b, Metal intensity in comparative historical perspective: China, North Asia, the United States and the Kuznets curve, Global Dynamic Systems Centre Working Papers, no. 6 (September), Global Dynamic Systems Centre, Canberra.

Maddison, A. 2001, The World Economy: A millennial perspective, Organisation for Economic Cooperation and Development, Paris.

2009, Historical Statistics of the World Economy: 1-2006AD, March update, Groningen Growth and Development Centre, Groningen, The Netherlands, <http://www.ggdc.net/maddison/>

National Bureau of Statistics (NBS) 2008, China Statistical Yearbook 2008, China Statistics Press, Beijing.

— various years, China Statistical Yearbook, China Statistics Press, Beijing.

Nelson, R. R. and Phelps, E. 1966, 'Investment in humans, technological diffusion, and economic growth', American Economic Review, vol. 56 (May), pp. 69-75.

Nishioka, S. 2008, 'A Japanese climate policy based on science, equity and cooperation', Asia-Pacific Review, vol. 15, no. 1, pp. 1-11.

Ohkawa, K. and Rosovsky, H. 1968, 'Postwar Japanese growth in historical perspective: a second look', in L. Klein and K. Ohkawa (eds), Economic Growth: The Japanese experience since the Meiji era, Richard D. Irwin Inc., Homewood, Ill., pp. 3-35.

Perkins, D. H. and Rawski, T. G. 2007, Forecasting China's Economic Growth to 2025, <http://post.economics.harvard.edu/faculty/perkins/papers/ Chapter20.pdf $>$

Prasad, E., Rumbaugh, T. and Wang, Q., 2005, Putting the cart before the horse? Capital account liberalization and exchange rate flexibility in China, IMF Policy Discussion Paper, PDP/05/01, International Monetary Fund, Washington, DC. 
Rawski, T. G. 2008, Can China sustain rapid growth despite flawed institutions?, Paper presented to the Sixth International Symposium of the Centre for China-US Cooperation, University of Denver, Colorado, 30-31 May.

Rosen, D. H. and Houser, T. 2007, China Energy: A guide for the perplexed, May, Peterson Institute for International Economics, Washington, DC.

Rostow, W. W. 1971, The Stages of Economic Growth: A non-communist manifesto, Oxford University Press, New York.

- 1978, The World Economy: History and prospect, Macmillan, London.

Roubini, N. and Setser, B. 2005, Will the Bretton Woods 2 regime unravel soon? The risk of a hard landing in 2005-06, Paper prepared for Federal Reserve Bank of San Francisco and University of California at Berkeley symposium Revived Bretton Woods System: A new paradigm for Asian development, 4 February.

Shi, X. 2008, 'Can China's coal industry be reconciled with the environment?', in L. Song and W. T. Woo (eds), China's Dilemma: Economic growth, the environment and climate change, Asia Pacific Press and Brookings Institution Press, Canberra and Washington, DC, pp. 367-91.

Snooks, G. D. 1997, The Ephemeral Civilisation: Exploding the myth of social evolution, Routledge, London.

1999, Global Transition: A general theory of economic development, Macmillan, London.

2009, Climate mitigation or technological revolution? A critical choice of futures, Global Dynamic Systems Centre Working Papers, no. 10 (February), Global Dynamic Systems Centre, Canberra.

Solow, R. M. 1957, 'Technical change and the aggregate production function', Review of Economics and Statistics, vol. 39, no. 3 (August), pp. 312-20.

Song, L. and Yu, S. 2007, 'China's demand for energy: a global perspective', in R. Garnaut and L. Song (eds), China: Linking markets for growth, Asia Pacific Press, Canberra, pp. 225-47. 
Song, L. 2005, 'Interest rate liberalisation in China and the implications for non-state banking', in Y. Huang, A. Saich and E. Steinfeld (eds), Financial Sector Reform in China, Harvard University Asia Center, Cambridge, Mass., pp. 111-30.

Stern, N. 2007, The Economics of Climate Change: The Stern review, Cambridge University Press, Cambridge and New York.

2008, 'The economics of climate change', American Economic Review: Papers \& Proceedings, vol. 98, no. 2, pp. 1-37.

Taylor, J. B. 2008, The financial crisis and the policy responses: an empirical analysis of what went wrong, Keynote address at the Bank of Canada, Ottawa, November.

Trebilcock, C. 1986, The Industrialisation of the Continental Powers 1780-1914, Longman, London.

United Nations (UN) 2007, World Urbanization Prospects: The 2007 revision, United Nations, New York, <http://www.un.org/esa/population/ publications/WUP2005/2005WUP_DataTables2.pdf $>$

United States Bureau of Statistics (USBS) 1901, Statistical Abstract of the United States 1900-01-Twenty-Third Number, Prepared under direction from the Secretary of the Treasury, United States Bureau of Statistics, Washington, DC, <http://www2.census.gov/prod2/ statcomp/documents/1900-01.pdf>

United States Federal Highway Administration (USFHA) 2008, Highway Statistics 2007, United States Federal Highway Administration, <http://www.fhwa.dot.gov/policyinformation/statistics/2007/vmt421.cfm>

US Federal Reserve 2009, Flow of Funds Accounts, United States Federal Reserve < http://www.federalreserve.gov/releases/zl/>

United States Geological Survey (USGS) various years, Minerals Yearbooks, United States Geological Survey, <http://minerals.usgs.gov/minerals/ pubs/>

Wing, I. S. 2008, 'Explaining the declining energy intensity of the US economy', Resource and Energy Economics, vol. 30, pp. 21-49.

Zhang, J., Gao, X. and Li, H. 2007, Global Economic Evolution: Structure, logic and China factor, The Renmin University Press, Beijing. 
Zhou, X. 2008, On savings ratio, Address to the High Level Conference, Central Bank of Malaysia, Kuala Lumpur, 10 February 2009, <http://www.bis.org/review/r090327b.pdf>

\section{Zhuang, G. 2008, 'How will China move towards becoming a low carbon economy', China \& World Economy, vol. 16, no. 3, pp. 93-105.}

\section{Endnotes}

1. The citation of a single work for these authors is an obvious understatement. The work of quantitative economic history is by its very nature a labour of decades. It is assumed that readers will be familiar with their broad contributions and will forgive a lean attitude to referencing in this context.

2. This section includes large amounts of data derived from a great many sources. To assist readability in the text, referencing will be kept to a minimum.

3. According to the study by CEIC and Goldman Sachs (2005), in 2004, capital stocks per worker in the United States, Japan and China were US\$149 000, US\$177 000 and US\$2600, respectively (calculated using 1984 prices).

4. We define industrial profit margins as the share of profits in total sales.

5. The fact that industrial sales exceed GDP by a large margin should not be alarming, as sales are a gross concept that does not control for intra and inter-industry transactions and import content. GDP, as a value-added concept, avoids this double-counting problem.

6. Of course, our analysis implies that from a long-run structural perspective, Chinese domestic demand will catch up to supply in the heavy industrial field. However, that long-run view does not exclude the possibility of pronounced cyclical deviations between the two, such as the current episode.

7. The Kaya identity is defined as $\mathrm{CO}_{2}$ emission $=$ population ${ }^{*}(\mathrm{GDP} / \text { population })^{*}($ energy/ $\mathrm{GDP})^{*}\left(\mathrm{CO}_{2}\right.$ /energy).

8. This is because greater human availability of human capital reduces a country's costs of adopting sophisticated techniques or equivalently raises the return to this adoption of new technology (Barro and Sala-i-Martin 2004).

9. In 1870, the United Kingdom accounted for 32 per cent of world total industrial output. Its energy consumption was five times that of the United States and Germany, six times that of France and 155 times that of Russia (Zhang et al. 2007).

10. PPP GDP levels are used in compiling this measure. Improvement is less pronounced under other measurement regimes.

11. Note that these elasticities are based on local currency values of GDP and energy consumption.

12. These conditions include that the difference in wage costs between the leading nation and potential challengers is large, experience in the old technology becomes rapidly obsolete and the new technology must ultimately offer the possibility of substantial productivity improvement over the old (Brezis et al. 1991).

13. For example, it is reported that worldwide investment in renewable energy has grown by 65 per cent a year since 2004 and is projected to reach US $\$ 600$ billion a year by 2020 (The 